\title{
INVENTÁRIO E AVALIAÇÃO DO PATRIMÔNIO NATURAL GEOLÓGICO DA REGIÃO DE RIO CLARO (SP)
}

\author{
Rogério Rodrigues RIBEIRO \\ Sérgio Ricardo CHRISTOFOLETTI \\ Alessandro BATEZELLI \\ Fernando Cilento FITTIPALDI (In Memoriam) \\ Denise ZANCHETTA
}

\begin{abstract}
RESUMO
O presente trabalho discute a abordagem metodológica utilizada no inventário e na avaliação de geossítios na região do Município de Rio Claro, uma das primeiras experiências no Estado de São Paulo. Observou-se que a inexistência de uma proposta para a sistematização do inventário do patrimônio geológico em nível estadual ou nacional, que resgate a história geológica da área estudada, dificultou os trabalhos de inventário e de avaliação propostos. A metodologia utilizada e adaptada para a área de estudo permitiu identificar onze geossítios com valor científico e amplo uso potencial. Destes geossítios, quatro também apresentam potencial para serem incluídos nos inventários nacional e internacional, indo ao encontro da proposta de conservação do patrimônio natural mundial da UNESCO. Assim, são lançadas as primeiras etapas para o desenvolvimento de uma estratégia de conservação do patrimônio geológico da área de estudo, que atualmente se encontra sob ameaça e necessita de políticas públicas para a sua gestão.
\end{abstract}

Palavras-chave: conservação, geodiversidade, inventário, patrimônio geológico, Rio Claro (SP).

\section{ABSTRACT}

This paper discusses the methodological approach used in the inventory and evaluation of geosites in the Rio Claro region, one of the first studies on this topic in the state of São Paulo. This region is characterized by a rich geodiversity, including relevant geosites with speleological, stratigraphical, geomorphological, palaeoenvironmental, paleontological and sedimentological content. The absence of a proposal for a systematic inventory of geological heritage at state or national level, considering the geological history of the area studied, made it difficult to inventory and evaluate the geosites. The methodology used in this study, already applied in European countries, was adapted for the study area and identified eleven geosites with great scientific value and broad potential use. Four out of the eleven geosites are in accordance with the UNESCO proposal for conservation of the world natural heritage and can be included in national and international inventories. Therefore, the first steps toward the development of a strategy for the conservation of the geological heritage of the study area are presented in this paper. These steps are very important since this area is currently under threat and public policies are needed for its better management.

Keywords: conservation, geodiversity, inventory, geological heritage, Rio Claro (SP). 


\section{INTRODUÇÃO}

A humanidade tem direcionado maciços recursos em ações de pesquisa, conservação e divulgação dos recursos naturais ligados à fauna e à flora, componentes da Biodiversidade. No entanto, pouco se divulga e se investe na defesa e na divulgação da Geodiversidade, base principal de suporte da Biodiversidade. Entende-se por Geodiversidade a "variedade de ambientes geológicos, fenômenos e processos ativos que dão origem aos minerais, rochas, solos, paisagens, fósseis e outros depósitos superficiais que dão suporte para a vida na Terra" (STANLEY 2000).

Da mesma forma que existem espécies da biodiversidade consideradas fundamentais para o conhecimento e funcionamento dos ecossistemas, a compreensão da história geológica de nosso planeta é possível por meio da reunião de geossítios. Um geossítio representa a ocorrência de um ou mais elementos da geodiversidade aflorantes, quer em resultado da ação de processos naturais, quer devido à intervenção humana, bem delimitados geograficamente e que apresente valor singular do ponto de vista científico, cultural, pedagógico, turístico, paisagístico ou outro (BRILHA 2005). Entende-se que o coletivo de geossítios compõe o patrimônio natural geológico (abiótico) de um determinado espaço. Este bem natural, representante da geodiversidade, também requer significativos investimentos em pesquisa e conservação para as futuras gerações. Segundo a Joint Nature Conservation Committee (JNCC apud CARCAVILLA URQUI et al. 2007), o interesse para o estudo e conservação do Patrimônio Geológico se resume em quatro aspectos:

1) a importância para a pesquisa;

2) o estudo da história da Terra e as correlações internacionais;

3) o interesse para a realização de modelos de evolução natural, importância para a educação e para a divulgação e,

4) seu interesse como recurso cultural e ambiental.

A preocupação mundial com a proteção desse patrimônio natural teve como datas marcantes a "Convenção para a Proteção da Flora, da Fauna e das Belezas Panorâmicas Naturais dos Países da América" (Washington, em 1940), a "Convenção de Argel Para a Conservação da Natureza e dos Recursos Naturais" (Argel, em 1968) e a mais importante, a "Convenção de Proteção ao Patrimônio Mundial, Cultural e Natural", promovida pela UNESCO (Paris, em 1972). Esta última teve como objetivo fundamental reconhecer os sítios culturais e naturais em âmbito mundial, de interesse excep- cional e de valor universal, de modo que sua proteção seja considerada responsabilidade de toda a humanidade.

O Brasil ratifica e assume o compromisso perante esta Convenção por meio da emissão do Decreto Federal no 80.978/77. As primeiras ações nacionais ocorrem quando o Departamento Nacional da Produção Mineral (DNPM) cria o Grupo de Trabalho Nacional de Sítios Geológicos e Paleobiológicos em 1993, substituída pela Comissão Brasileira dos Sítios Geológicos e Paleobiológicos (SIGEP) em 1997. Essa comissão é representada por várias instituições científicas e tem como principal objetivo identificar sítios geológicos e paleobiológicos com potencial para ingressarem no inventário do patrimônio geológico nacional.

Fora do âmbito Federal, alguns estados brasileiros também tiveram iniciativas voltadas à pesquisa, conservação e divulgação dos monumentos naturais, como Rio de Janeiro, Paraná, Bahia, Minas Gerais, Rio Grande do Norte e São Paulo. No Estado de São Paulo, algumas ações diretas e indiretas de preservação de elementos significativos da geodiversidade paulista foram implantadas com sucesso, como por exemplo, a criação dos Parques Municipais Rocha Moutonnée (1991) e Varvito de Itu (1995), localizados respectivamente nas cidades paulistas de Salto e Itu, e a criação de unidades de conservação estaduais, como o Parque Estadual Turístico do Alto Ribeira, criado em 1958, que protege o carste e cavernas lá existentes.

Ainda podem ser citadas algumas políticas públicas paulistas como o lançamento dos projetos Monumentos Geológicos do Estado de São Paulo (2007) e Monumentos Geológicos da Região de Rio Claro (2007), ambos desenvolvidos junto ao Instituto Geológico da Secretaria de Estado do Meio Ambiente de São Paulo (SMA/SP). Em 2009, por meio da Resolução SMA n ${ }^{\circ} 76$, foi instituído no âmbito da SMA o Conselho Estadual de Monumentos Geológicos (CoMGeo-SP), com o objetivo principal de receber e avaliar propostas de candidatura de geossítios à categoria de Monumento Geológico. Uma vez aprovados, são inseridos no Inventário Paulista de Monumentos Geológicos.

O projeto Monumentos Geológicos da Região de Rio Claro (SP) teve por finalidade identificar, conservar e divulgar o rico patrimônio geológico lá existente, bem como propor novos geossítios/ monumentos geológicos para o Inventário Paulista.

A região de entorno do Município de Rio Claro (SP) é conhecida por apresentar um patrimônio natural bastante rico, reunindo geossítios com conteúdo espeleológico, estratigráfico, geomorfológico, 
paleoambiental, paleontológico e sedimentológico Tão significativo é o seu potencial geológico que em 1969 a cidade de Rio Claro foi escolhida para sediar o primeiro curso de Geologia do interior do Estado de São Paulo. Entretanto, esse bem natural encontra-se ameaçado. A expansão urbana, a mineração e o agronegócio regional representam riscos a esse patrimônio, sendo urgente a elaboração e o desenvolvimento de uma estratégia regional de conservação.

Segundo BRILHA (2005), para se elaborar uma estratégia de conservação é necessário o desenvolvimento de algumas etapas sequenciais: inventário, quantificação, classificação, conservação, valorização e divulgação do patrimônio. A etapa de inventário na região de Rio Claro foi iniciada por ZAINE \& PERINOTTO (1996), ao promover a identificação e descrição dos patrimônios naturais e da história geológica da região, em especial na região da bacia hidrográfica do Rio Corumbataí. Além da abordagem descritiva e científica desses patrimônios (Tabela 1), também indicaram suas potencialidades e as ameaças incidentes.

Dessa forma, o presente artigo tem como objetivo contribuir para a elaboração de uma estratégia de conservação desse patrimônio, por meio da continuidade dos trabalhos de inventário dos sítios com valor científico e da implantação da etapa de avaliação. Em função da inexistência de uma proposta para a sistematização do inventário do patrimônio geológico em nível estadual ou nacional, que oriente os trabalhos, foram utilizadas metodologias estrangeiras adaptadas às condições geográficas da área de estudo. Ressalta-se que a presente contribuição não esgota o potencial geológico da região de Rio Claro, cabendo a continuidade do levantamento desse patrimônio em novas pesquisas.

TABELA 1 - Patrimônios Naturais identificados na área de estudo (Adaptado de ZAINE \& PERINOTO 1996).

\begin{tabular}{|c|c|}
\hline Monumentos/Feições & Nome/Ocorrência \\
\hline Cuestas & $\begin{array}{l}\text { - Serra de Itaqueri } \\
\text { - Serra de Santana (dos Padres) } \\
\text { - Serra do Cuscuzeiro. }\end{array}$ \\
\hline Morros testemunhos & $\begin{array}{l}\text { - Morro do Bizigueli } \\
\text { - Morro da Guarita } \\
\text { - Morro do Pelado } \\
\text { - Morro do Baú } \\
\text { - Morros do Camelo } \\
\text { - Morro do Cuscuzeiro } \\
\text { - Morro Grande }\end{array}$ \\
\hline Cavernas & $\begin{array}{l}\text { - Gruta do Fazendão } \\
\text { - Gruta Boca do Sapo } \\
\text { - Gruta Abrigo da Glória } \\
\text { - Gruta da Toca } \\
\text { - Gruta do Retiro } \\
\text { - Caverna do Fazendão/Cantagalo }\end{array}$ \\
\hline Recursos hidricos & $\begin{array}{l}\text { - Rio Corumbataí } \\
\text { - Ribeirão Claro }\end{array}$ \\
\hline Quedas d'água & $\begin{array}{l}\text { - Analândia (Serra do Itaqueri) } \\
\text { - Wiechman e Altarugio (Rio Cabeça) } \\
\text { - Usina da CESP (Rio Corumbataí) }\end{array}$ \\
\hline Formações geológicas de interesse econômico & $\begin{array}{l}\text { - Formação Corumbatá (Indústria Cerâmica) } \\
\text { - Formação Pirambóia (Areia Industrial) } \\
\text { - Formação Rio Claro (Areia Industrial) }\end{array}$ \\
\hline Jazigos fossíliferos & $\begin{array}{l}\text { - Formação Irati } \\
\text { - Formação Corumbataí } \\
\text { - Formação Pirambóia }\end{array}$ \\
\hline Sítios arqueológicos & $\begin{array}{l}\text { - Sítio Urbano de Rio Claro } \\
\text { - Sítio Serra d'Água/Boer }\end{array}$ \\
\hline Cobertura vegetal & $\begin{array}{l}\text { - Fazenda São José (Mata Atlântica) } \\
\text { - Matas ciliares } \\
\text { - Remanescentes de cerrado }\end{array}$ \\
\hline
\end{tabular}




\section{2 ÁREA DE ESTUDO}

A área de estudo localiza-se na porção centro-sudeste do Estado de São Paulo e abrange os municípios de Analândia, Charqueada, Corumbataí, Ipeúna, Itirapina, São Pedro, Rio Claro, Limeira e Santa Gertrudes (Figura 1). O sistema viário local é privilegiado, com destaque para as rodovias Anhanguera, (SP 330), Washington Luís (SP 310), Bandeirantes (SP 348), Fausto Santomauro (SP 127) e Wilson Finardi (SP 191). A rede hidrográfica é representada pela Bacia do Rio Corumbataí (Bacia PCJ - Piracicaba, Capivari, Jundiaí-URGHI 5) e a vegetação predominante é composta pela Floresta Estacional Semidecidual e Savanas (cerrados).

Nesse trabalho foram identificados onze geossítios localizados em cinco municípios: Analândia, Charqueada, Ipeúna, Limeira e Rio Claro. Estas cidades pertencem à Região Administrativa de Campinas, na Mesorregião de Piracicaba e entre as Regiões de Governo de Rio Claro e de Piracicaba (SEADE 2011).

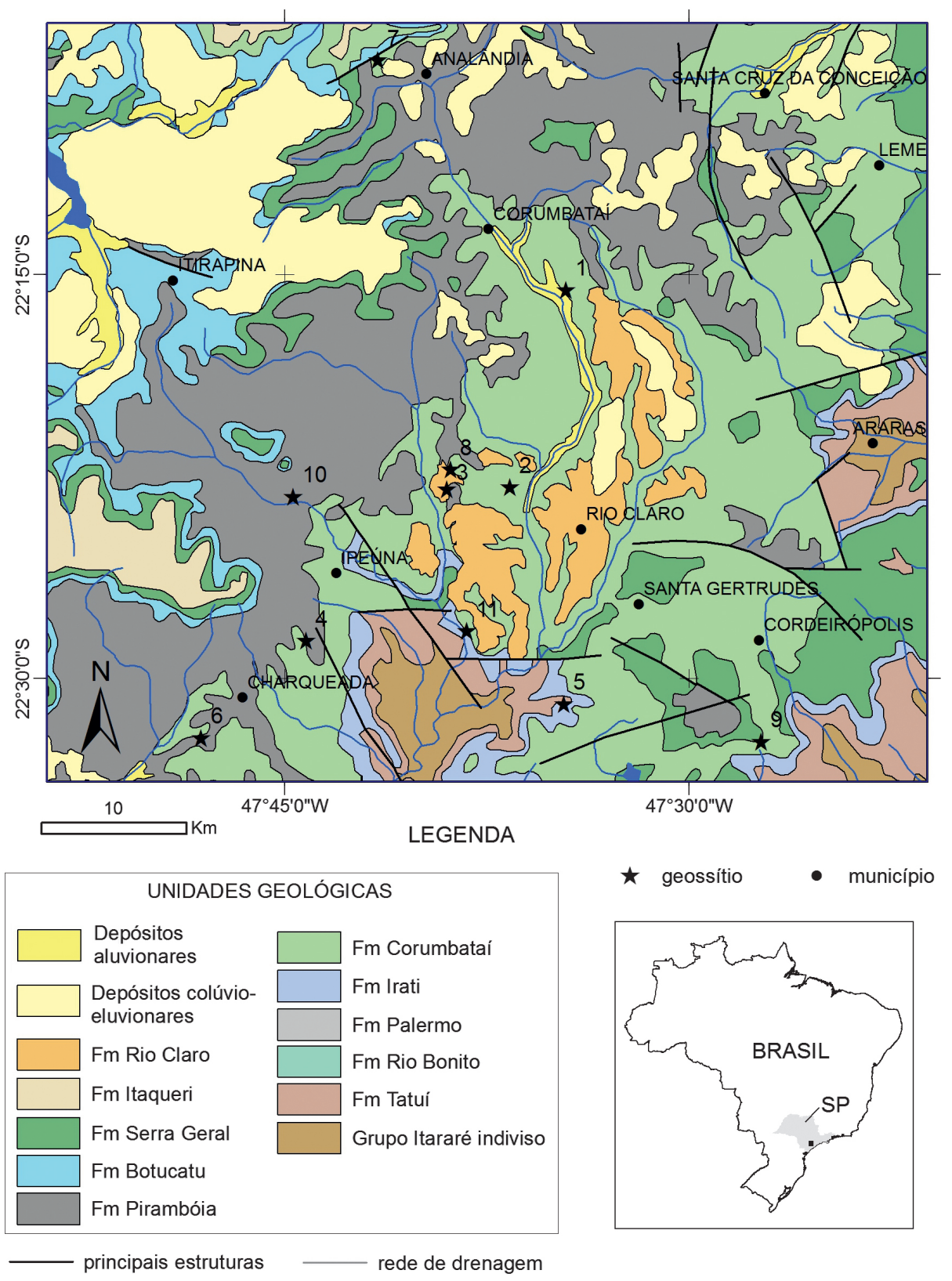

FIGURA 1 - Contexto geológico da área de estudo e localização dos geossítios identificados nesse trabalho (Modificado de PERROTTA et al. 2005) 
Na tabela 2 e na figura 2 observam-se alguns dados sócio-econômicos desses munícipios, como área, população, renda, indicadores de qualidade de vida e distribuição de empregos por setor econômico.

TABELA 2 - Principais dados sócio-econômicos da área de estudo. Fonte: Fundação SEADE (2011). ${ }^{1}$ Renda per Capta (salários mínimos). ${ }^{2}$ Os indicadores do IPRS (Índice Paulista de Responsabilidade Social) sintetizam a situação de cada município no que diz respeito à riqueza, escolaridade e longevidade, e quando combinados, geram uma tipologia que classifica os municípios do Estado de São Paulo em cinco grupos: Grupo I - Municípios que se caracterizam por um nível elevado de riqueza com bons níveis nos indicadores sociais; Grupo II - Municípios que, embora com níveis de riqueza elevados, não são capazes de atingir bons indicadores sociais; Grupo III - Municípios com nível de riqueza baixo, mas com bons indicadores sociais; Grupo IV - Municípios que apresentam baixos níveis de riqueza e níveis intermediários de longevidade e/ou escolaridade e Grupo V - Municípios mais desfavorecidos do Estado, tanto em riqueza como nos indicadores sociais. ${ }^{3}$ Índice de Desenvolvimento Humano - Indicador que focaliza o município como unidade de análise, a partir das dimensões de longevidade, educação e renda: (a) - Baixo desenvolvimento humano, quando o IDHM for menor que 0,500; (b) - Médio desenvolvimento humano, para valores entre 0,500 e 0,800 e (c) - Alto desenvolvimento humano, quando o índice for superior a 0,800 .

\begin{tabular}{cccccc}
\hline Municipio & Área $\left(\mathrm{km}^{2}\right)$ & População & Renda $^{I}$ & IRPS $^{2}$ & $I^{2} H^{3}$ \\
\hline Analândia & 326,60 & 4.358 & 2,12 & Grupo I & 0,804 \\
Charqueada & 176,00 & 15.29 & 1,86 & Grupo V & 0,782 \\
Ipeúna & 190,53 & 6.204 & 2,21 & Grupo III & 0,786 \\
Limeira & 580,98 & 278.58 & 2,44 & Grupo I & 0,814 \\
Rio Claro & 498,01 & 188,0 & 3,10 & Grupo I & 0,825 \\
\hline
\end{tabular}

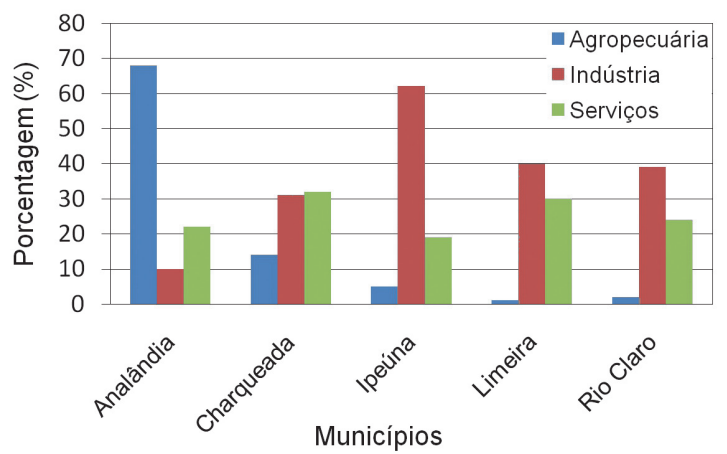

FIGURA 2 - Distribuição dos empregos por setor econômico por município. Fonte: SEADE (2011).

A área de estudo situa-se no setor paulista do flanco nordeste da Bacia Sedimentar do Paraná, representada por rochas sedimentares e vulcânicas das eras Paleozoica (formações Itararé, Tatuí, Corumbataí e Iratí), Mesozoica (formações Pirambóia, Botucatu e Serra Geral) e Cenozoica (formações Rio Claro e depósitos recentes) (Figura 1). Trata-se de uma extensa bacia intracratônica situada na parte central do Continente Sul-Americano abrangendo uma área de $1.700 .000 \mathrm{~km}^{2}$, sendo $160.000 \mathrm{~km}^{2}$ somente no Estado de São Paulo. É umas das bacias sedimentares mais bem estudadas, devido à facilidade de acesso, extensa exposição de afloramentos e pela grande importância econômica de seus recursos minerais.

A área de estudo está inserida na transição entre a Depressão Periférica e as Cuestas Basálticas, conforme ALMEIDA (1964).

\section{METODOLOGIA}

A realização do inventário do patrimônio geológico da região de Rio Claro (SP) tem como principal finalidade promover a proteção deste bem natural frente às ameaças antrópicas. Para isso é importante que se defina uma estratégia de conservação, que consiste "na concretização de uma metodologia de trabalho que vise sistematizar as tarefas no âmbito da conservação do Patrimônio Geológico de uma dada área”. Estas tarefas devem ser agrupadas nas seguintes etapas sequenciais: inventário, quantificação, classificação, conservação, valorização, divulgação e monitorização" (BRILHA 2005). 
A primeira etapa (inventário) serve para suportar o desenvolvimento das outras ações relacionadas com a geoconservação, uma vez que compreende a identificação e caracterização dos geossítios, promovendo a sistematização do conhecimento geológico em uma base de dados (LIMA 2008).

$\mathrm{Na}$ figura 3 são apresentadas as etapas para o inventário e avaliação do patrimônio geológico da região de Rio Claro.

ETAPA 1

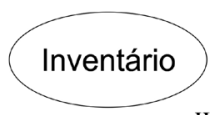

WIMBLEDON et al. ( 1991 ), SHARPLES (2002)

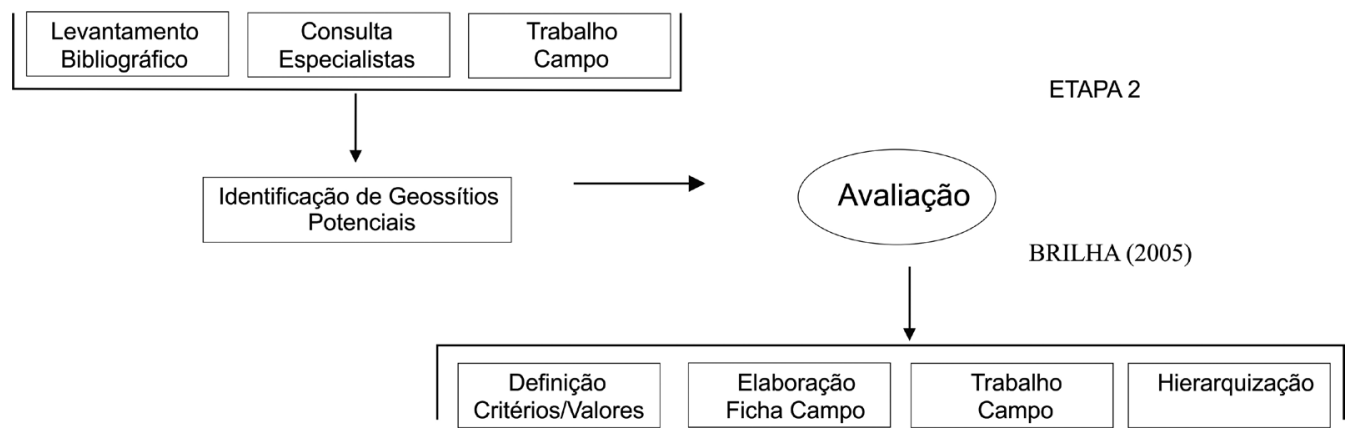

FIGURA 3 - Etapas para o inventário e avaliação do patrimônio geológico da região de Rio Claro.

\subsection{Inventário}

CUMBE (2007) explica que o inventário consiste no levantamento e registro sistemático de geossítios que ocorrem numa determinada área, após reconhecimento prévio da mesma, por meio de levantamentos bibliográficos e trabalhos de campo. Durante esse processo, é feito apenas o levantamento daqueles sítios com características geológicas relevantes. É fundamental a coleta pormenorizada de informação, eventualmente com o uso de uma ficha para caracterização dos geossítios, adaptada em função dos objetivos específicos e das características de cada região.

$\mathrm{O}$ inventário iniciado por ZAINE \& PERINOTTO (1996), bem como o realizado nesse trabalho, não seguiram nenhuma proposta de sistematização de inventário do patrimônio geológico, em nível nacional ou estadual, baseada em contextos geológicos que resgatem a história geológica de um determinado espaço. Devido a esse fato e contando com a participação de uma única equipe multidisciplinar de geocientistas, a continuidade deste inventário utilizou a combinação das seguintes abordagens metodológicas:

a) WIMBLEDON et al. (1999): Seleção de geossítios dotados de características superlativas: metodologia que dispensa pesquisas sistemáticas, contemplando geossítios dotados de características superlativas, ignorando o enquadramento ou a contextualização do mesmo. b) SHARPLES (2002): Inventário de Reconhecimento: consiste na identificação e seleção de Pontos de Interesse Geológico (PIG's), mediante uma revisão bibliográfica e a consulta a especialistas, com a finalidade de conseguir uma lista dos lugares de maior relevância. Este sistema é rápido e requer poucos recursos, já que não realiza uma nova investigação. Não requer um estudo geológico de síntese, uma vez que se pressupõe o conhecimento geológico da área pelos autores do estudo e dos especialistas consultados.

\subsection{Avaliação}

Nesta segunda etapa foram realizadas as seguintes atividades:

a) Definição dos critérios e valores;

b) Elaboração da ficha de campo e;

c) Hierarquização.

\subsubsection{Definição dos critérios e valores}

Com base no trabalho de UCEDA (2000), BRILHA (2005) apresentou uma proposta que estabelece um conjunto de critérios e valores para os geossítios (Tabela 3). 
TABELA 3 - Critérios e valores para geossítios (BRILHA 2005).

\begin{tabular}{|c|c|}
\hline Critério & BRILHA (2005) \\
\hline$A 1$ & Abundância/raridade na área em estudo (no exemplares): 5 - $(0-1) ; 4$ - (2-4); 3 - (5-10); 2 - (11-20); 1 - (> 20). \\
\hline$A 2$ & xtensão $\left(\mathrm{m}^{2}\right): 5$ - Superior a 1.000.000; $4-100.000$ a $1.000 .000 ; 3-10.000$ a $100.000 ; 2-1.000$ a $10.000 ; 1$ - Menor que 1.000. \\
\hline$A 3$ & $\begin{array}{l}\text { Grau de conhecimento cientifico: } 5 \text { - Mais de uma tese de doutorado ou dissertação de mestrado e mais de um artigo publicado } \\
\text { em revista internacional; } 4 \text { - Pelo menos uma tese de doutorado ou dissertação de mestrado ou mais de um artigo publicado em } \\
\text { revista internacional ou mais de cinco artigos publicados em revistas nacionais; } 3 \text { - Pelo menos um artigo publicado em revista } \\
\text { internacional ou quatro artigos publicados em revistas nacionais; } 2 \text { - Algumas notas breves publicadas em revistas nacionais ou } \\
\text { um artigo publicado em revistas regionais/locais; } 1 \text { - Não existem trabalhos publicados. }\end{array}$ \\
\hline A4 & Utilidade como modelo para ilustração de processos geológicos: 5 - Muito útil; 3 - Moderadamente útil; 1 - Pouco útil. \\
\hline A5 & $\begin{array}{l}\text { Diversidade de elementos de interesse: } 5 \text { - Cinco ou mais tipos de interesse; } 4 \text { - Quatro tipos de interesse; } 3 \text { - Três tipos de } \\
\text { interesse; } 2 \text { - Dois tipos de interesse; } 1 \text { - Um tipo de interesse. }\end{array}$ \\
\hline A6 & $\begin{array}{l}\text { Local tipo: } 5 \text { - É reconhecido como um local-tipo na área de estudo; } 3 \text { - É reconhecido como local-tipo secundário; } 1 \text { - Não é } \\
\text { reconhecido como local-tipo. }\end{array}$ \\
\hline$A 7$ & $\begin{array}{l}\text { Associação com elementos do Patrimônio Cultural: } 5 \text { - Existem evidências arqueológicas e de outro elemento de interesse } \\
\text { cultural; } 4 \text { - Existem evidências arqueológicas e de algum outro tipo; } 3 \text { - Existem somente vestígios arqueológicos; } 2 \text {-Existem } \\
\text { elementos de interesse não arqueológico; } 1 \text { - Não existem elementos de interesse. }\end{array}$ \\
\hline$A 8$ & $\begin{array}{l}\text { Associação com outros elementos do meio natural: } 5 \text { - Fauna e flora notáveis pela sua abundância, grau de desenvolvimento } \\
\text { ou presença de espécies de especial interesse; } 3 \text { - Presença de fauna ou flora de interesse moderado; } 1 \text { - Ausência de outros } \\
\text { elementos naturais de interesse. }\end{array}$ \\
\hline A9 & $\begin{array}{l}\text { Estado de conservação: } 5 \text { - Perfeitamente conservado, sem evidências de deterioração; } 4 \text { - Alguma deterioração; } 3 \text { - Existem } \\
\text { escavações, acumulações ou construções mas que não impedem a observação das suas características essenciais; } 2 \text { - Existem } \\
\text { numerosas escavações, acumulações ou construções que deterioram as suas características essenciais do Geossítio; } 1 \text { - Fortemente } \\
\text { deteriorado. }\end{array}$ \\
\hline$B 1$ & $\begin{array}{l}\text { abilidade para o desenvolvimento de atividades (cientificas, pedagógicas, turísticas e recreativas); } 5 \text { - É possível realizar } \\
\text { ividades científicas e pedagógicas; } 3 \text { - É possível realizar atividades científicas ou pedagógicas; } 1 \text { - É possível realizar outros } \\
\text { bos de atividades. }\end{array}$ \\
\hline$B 2$ & ondições de observação: 5 - Ótimas; 3 - Razoáveis; 1 - Deficientes. \\
\hline B3 & $\begin{array}{l}\text { Possibilidade de coleta de objetos geológicos: } 5 \text { - É possível a coleta de minerais, rochas e fósseis sem a perda da integridade } \\
\text { do Geossítio; } 4 \text { - É possível a coleta de minerais ou rochas ou fósseis sem a perda da integridade do Geossítio; } 3 \text { - É possível a } \\
\text { coleta de algum tipo de objeto, embora com restrições; } 2 \text { - É possível a coleta de algum tipo de objeto embora comprometa a } \\
\text { integridade do Geossítio; } 1 \text { - Não se pode recolher amostras. }\end{array}$ \\
\hline B4 & $\begin{array}{l}\text { Acessibilidade: } 5 \text { - Acesso direto a partir de estradas nacionais; } 4 \text { - Acesso direto a partir de estradas estaduais/municipais; } \\
3 \text { - Acesso direto a partir de caminhos não-asfaltados mas facilmente transitáveis por automóveis; } 2 \text { - O Geossítio localiza-se } \\
\text { a menos de } 1 \mathrm{~km} \text { de algum caminho utilizável por automóveis; } 1 \text { - O Geossítio localiza-se a mais de } 1 \mathrm{~km} \text { de algum caminho } \\
\text { utilizável por automóveis. }\end{array}$ \\
\hline B5 & $\begin{array}{l}\text { oximidade a povoações: } 5 \text { - Existe uma povoação com mais de } 10.000 \text { habitantes e com oferta hoteleira variada a menos de } 5 \\
\text { a, } 4 \text { - Existe uma povoação com menos de } 10.000 \text { habitantes e com oferta hoteleira limitada a menos de } 5 \mathrm{~km} ; 3 \text { - Existe uma } \\
\text { voação com oferta hoteleira entre } 5 \text { a } 20 \mathrm{~km} ; 2 \text { - Existe uma povoação com oferta hoteleira entre } 20 \text { a } 40 \mathrm{~km} ; 1 \text { - Só existe } \\
\text { a povoação com oferta hoteleira a mais de } 40 \mathrm{~km} \text {. }\end{array}$ \\
\hline B6 & $\begin{array}{l}\text { Imero de habitantes: } 5 \text { - Existem mais de } 100.000 \text { hab. num raio de } 25 \mathrm{~km} \text {, } 4 \text { - Existem entre } 50.000 \text { e } 100.000 \text { hab. num raio } \\
25 \mathrm{~km} ; 3 \text { - Existem entre } 25.000 \text { e } 100.000 \text { hab. num raio de } 25 \mathrm{~km} ; 2 \text { - Existem entre } 10.000 \text { e } 25.000 \text { hab. num raio de } 25 \\
\text {; } 1 \text { - Existem menos de } 10.000 \text { hab. num raio de } 25 \mathrm{~km} \text {. }\end{array}$ \\
\hline$B 7$ & $\begin{array}{l}\text { ndições sócio-econômicas: } 5 \text { - Os níveis de rendimento per capita e de educação da área são superiores à média nacional e a taxa } \\
\text { desemprego é menor; } 3 \text { - Os níveis de rendimento per capita, de educação e de desemprego da área são equivalentes à média } \\
\text { cional; } 1 \text { - Os níveis de rendimento per capita, de educação e de desemprego da área são piores em relação à média nacional. }\end{array}$ \\
\hline$C 1$ & $\begin{array}{l}\text { Ameaças atuais ou potenciais: } \\
5 \text { - Zona rural, não sujeita a desenvolvimento urbanístico ou industrial nem a construção de infraestrutura e sem perspectiva } \\
\text { de estar submetida a tal; } 3 \text { - Zona de caráter intermediário, não estando especificamente previstos desenvolvimentos concretos, } \\
\text { mas que apresenta razoáveis possibilidades num futuro próximo; } 1 \text { - Zona inclú́da em áreas de forte expansão urbana ou } \\
\text { industrial ou em locais onde está prevista a construção de infraestrutura. }\end{array}$ \\
\hline$C 2$ & $\begin{array}{l}\text { tuação atual: } 5 \text { - Geossítio sem qualquer tipo de proteção legal; } 3 \text { - Geossítio incluído numa área com proteção legal (rede } \\
\text { tural, proteção municipal,...); } 1 \text { - Geossítio incluído numa área protegida integrada na Rede Nacional de Áreas Protegidas. }\end{array}$ \\
\hline C3 & $\begin{array}{l}\text { teresse para a exploração mineral: } 5 \text { - O geossítio encontra-se numa zona sem nenhum tipo de interesse mineiro; } 4 \text { - O geossítio } \\
\text { contra-se numa zona com índices minerais de interesse; } 3 \text { - O geossítio encontra-se numa zona com reservas importantes de } \\
\text { ateriais de baixo valor unitário, embora não esteja prevista a sua exploração imediata; } 2 \text { - O geossítio encontra-se numa zona } \\
\text { m reservas importantes de materiais de baixo valor unitário e em que é permitida a sua exploração; } 1 \text { - O geossítio encontra-se } \\
\text { ma zona com grande interesse mineiro para recursos com elevado valor unitário e com concessões ativas. }\end{array}$ \\
\hline C4 & Valor dos terrenos $\left(\right.$ euros $\left./ m^{2}\right): 5$ - Menor que $5 ; 4-6-10 ; 3-11-30 ; 2-31-60 ; 1-$ Superior a 60. \\
\hline C5 & $\begin{array}{l}\text { Regime de Propriedade: } 5 \text { - Terreno predominantemente pertencente ao Estado; } 4 \text { - Terreno predominantemente pertencente } \\
\text { o Município; } 3 \text { - Terreno parcialmente público e privado; } 2 \text { - Terreno privado pertencente a um só proprietário; } 1 \text { - Terreno } \\
\text { rivado pertencente a vários proprietários. }\end{array}$ \\
\hline C6 & $\begin{array}{l}\text { Fragilidade: } 5 \text { - Aspectos geomorfológicos que pelas suas grandes dimensões, relevo, etc., são dificilmente afetados, de } \\
\text { modo importante, pelas atividades humanas; } 4 \text { - Grandes estruturas geológicas ou sucessões estratigráficas de dimensões } \\
\text { quilométricas que, embora possam degradar-se por grandes intervenções humanas, a sua destruição é pouco provável; } 3 \text { - } \\
\text { Aspectos de dimensão hectométrica que podem ser destruídos em grande parte por intervenções não muito intensas; } 2 \text { - } \\
\text { Aspectos estruturais, formações sedimentares ou rochosas de dimensões decamétricas que podem ser facilmente destruídas } \\
\text { por intervenções humanas pouco expressivas; } 1 \text { - Aspectos de dimensão métrica, que podem ser destruídos por pequenas } \\
\text { intervenções ou jazidas minerais ou paleontológicas de fácil depreciação. }\end{array}$ \\
\hline
\end{tabular}


São indicados três critérios: Valor Intrínseco (A1-A9), Uso Potencial (B1-B7) e Necessidade de Proteção (C1-C6). Cada um dos critérios é quantificado numa escala de 1 a 5 . O valor final, que define cada geossítio, é determinado pela média simples destes três conjuntos de critérios ou de uma média ponderada, privilegiando um dado conjunto. Qualquer que seja a opção, o resultado da avaliação deve sempre indicar os resultados parciais e finais para cada um dos critérios A, B e C. Os critérios devem ainda ser usados para o enquadramento dos geossítios nos inventários de âmbito internacional, nacional, regional ou local.

Em relação à escala de valores, UCEDA (2000) esclarece que esse procedimento ajuda a diminuir, na medida do possível, a ambiguidade e a opinião do observador. Esclarece que numa escala de 1 a 5, o 1 corresponde ao "pior" e 5 ao "melhor", do ponto de vista de cada critério.

Segundo BRILHA (2005), os geossítios de âmbito internacional ou nacional devem possuir, em acumulação, os seguintes valores para os critérios abaixo:

\begin{tabular}{l|l}
$\mathrm{A} 1 \geq 3$ & $\mathrm{~B} 1 \geq 3$ \\
$\mathrm{~A} 3 \geq 4$ & $\mathrm{~B} 2 \geq 3$ \\
$\mathrm{~A} 6 \geq 3$ & \\
$\mathrm{~A} 9 \geq 3$ &
\end{tabular}

Os geossítios que não se enquadrem nestes valores devem ser considerados de âmbito regional ou local. Os geossítios de âmbito internacional ou nacional devem ser conservados independentemente da sua utilidade, porque estes são os geossítios mais importantes identificados na área em estudo. Os critérios A e C devem ser sobrevalorizados em relação ao critério $\mathrm{B}$. A avaliação de geossítios de âmbito internacional ou nacional pode ser feita a partir da expressão [A] e a dos geossítios de âmbito regional ou local pela expressão [B]:

$$
\begin{array}{ll}
\begin{array}{l}
\text { [A] }- \text { Ambito Internacional } \\
\text { ou Nacional }
\end{array} & \mathrm{Q}=(2 \mathrm{~A}+\mathrm{B}+1.5 \mathrm{C}) / 3 \\
{[\mathrm{~B}]-\text { Regional ou Local }} & \mathrm{Q}=(\mathrm{A}+\mathrm{B}+\mathrm{C}) / 3
\end{array}
$$

onde: Q é a avaliação final da relevância do geossítio (arredondada às décimas) e $\mathrm{A}, \mathrm{B}$ e $\mathrm{C}$ a soma dos resultados dos valores obtidos para cada conjunto de critérios.

Dessa forma, quanto maior o valor de Q, maior é a relevância do geossítio e, por conseguinte, maior a urgência em se aplicar as primeiras ações de conservação previstas na estratégia de geoconservação definida.

\subsubsection{Elaboração da ficha de campo}

A ficha de campo utilizada para a avaliação dos geossítios também teve como base a metodologia de BRILHA (2005) e a proposta de classificação do patrimônio geológico da The European Association for the Conservation of the Geological Heritage (PROGEO - Portugal). Ela contém campos para a identificação do geossítio (endereço, coordenadas, nome do proprietário, equipe, bacia hidrográfica, etc.), bem como campos voltados para os critérios intrínsecos dos geossítios (A), uso potencial (B) e necessidade de proteção (C). Também estão presentes os campos para inclusão da documentação gráfica, fotos, dados gráficos, explicação dos fenômenos geológicos (processos sedimentares, ígneos, metamórficos, formas de erosão, geologia aplicada) e bibliografia.

Entretanto, face às características geográficas da área de estudo, foram necessárias adaptações na ficha de campo, especialmente em alguns critérios e valores a serem aplicados na avaliação dos geossítios identificados na área, conforme disposto na Tabela 4. Os demais critérios foram utilizados sem adaptações.

Os dados obtidos com a ficha de campo foram tabulados em planilhas do software Excel (Microsoft - versão 2010), permitindo quantificar as variáveis experimentais por meio dos critérios (A, B e C) e aplicar as fórmulas para avaliação dos geossítios proposta por BRILHA (2005).

\subsection{Hierarquização}

A partir das etapas anteriores, foi possível realizar a hierarquização dos geossítios identificados, que indicou, a partir da maior pontuação recebida, a ordem de prioridade ou de necessidade de proteção dos mesmos.

\section{RESULTADOS}

4.1 Geossítios identificados e os critérios A, B e C.

$\mathrm{Na}$ área de estudo foram identificados onze pontos com valor científico (Figuras 1 e 4 e Tabelas 5 e 6), a saber:

- Ponto 1 -Afloramento Bivalves Fepasa (Ferraz): esta exposição da Formação Corumbataí é caracterizada pela grande concentração de conchas de bivalves, silicificados ou na forma de moldes internos e externos. Esses fósseis são importantes porque, além de contribuir para um conhecimento mais apurado da história deposicional da formação, apresentam grande potencial bioestratigráfico, inclusive em estudos relacionados com a deriva continental. 


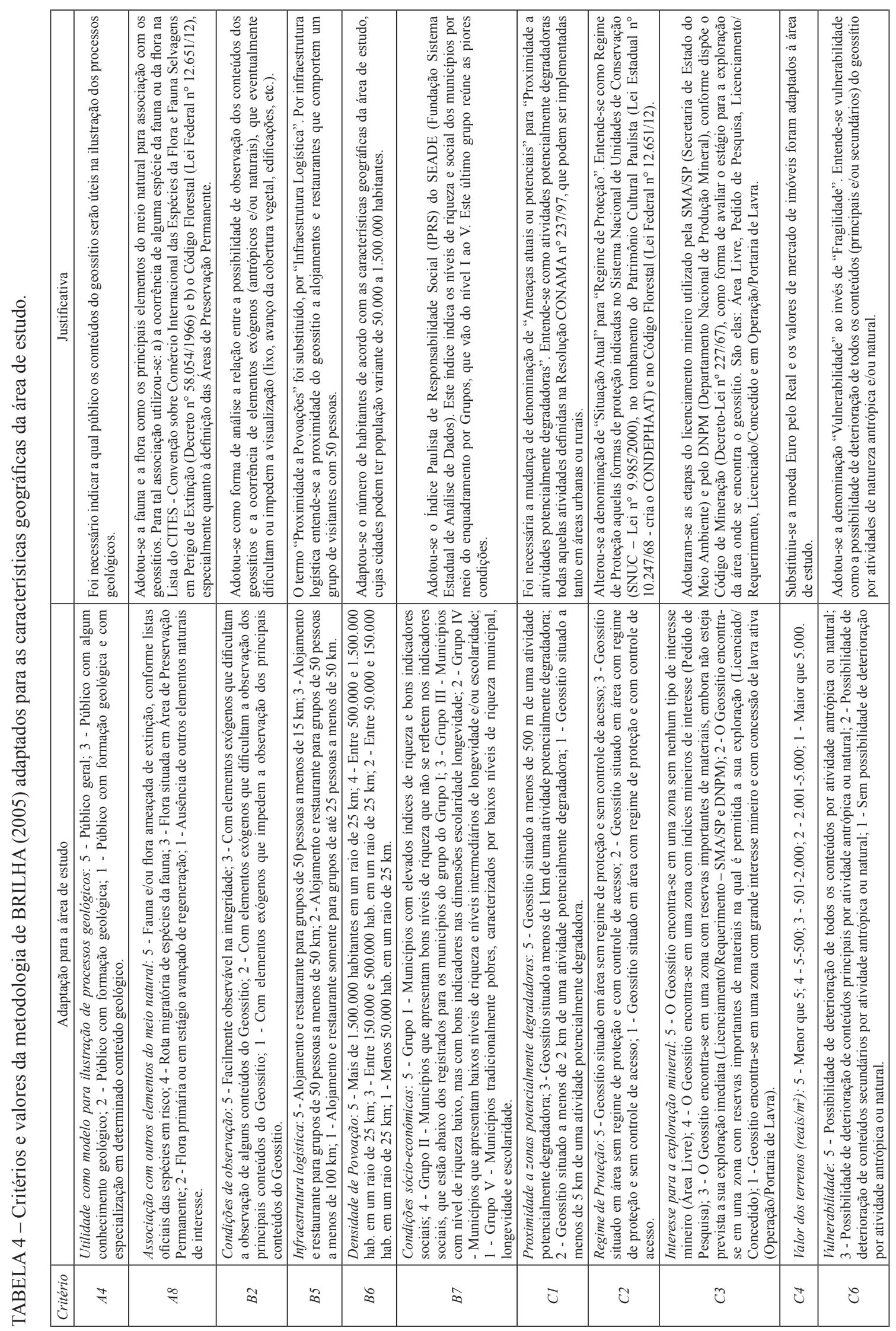




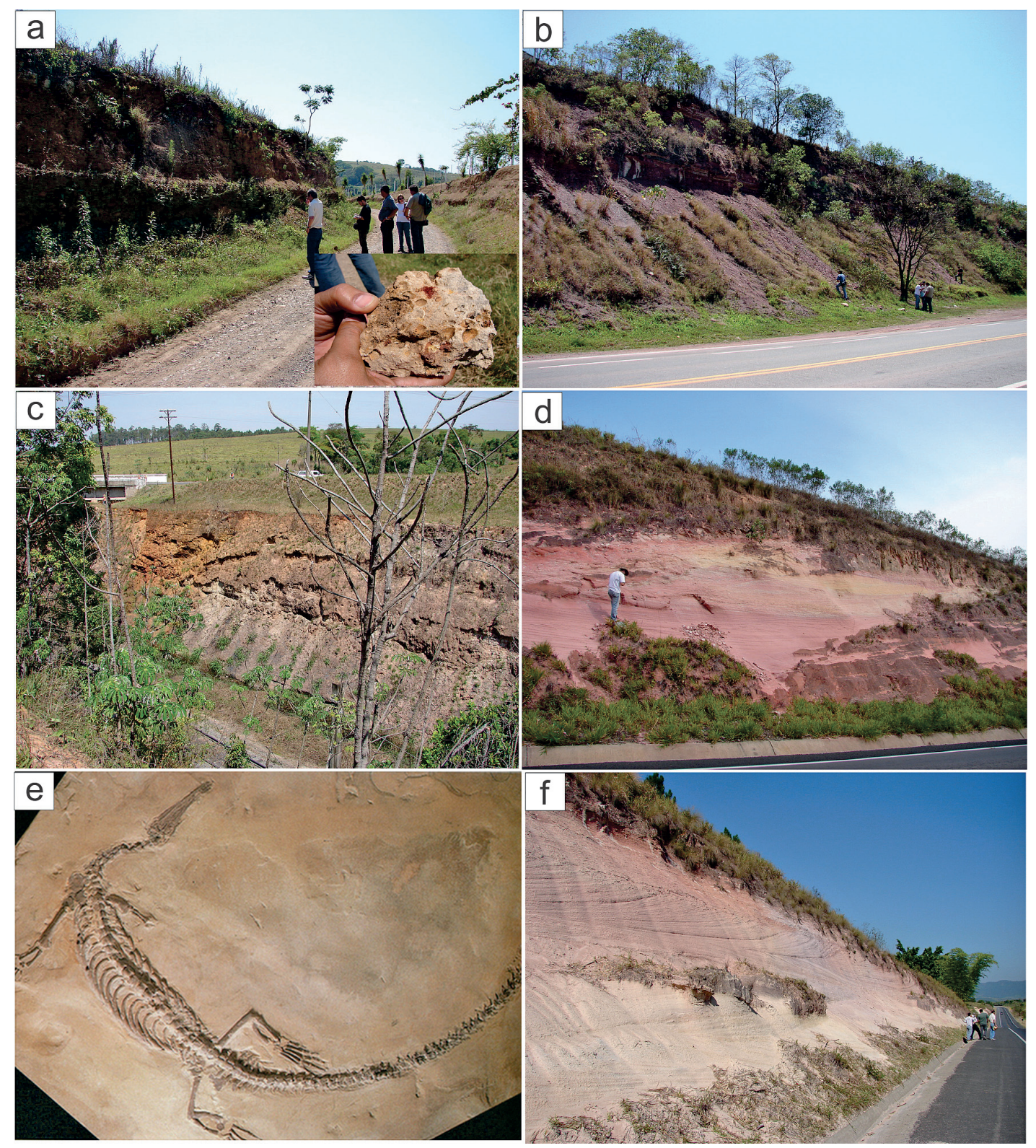

FIGURA 4 - Fotografias dos geossítios identificados na área de estudo. a) Ponto 1 - Bivalves-Fepasa (Ferraz) (Autor: Rogério R. Ribeiro). b) Ponto 02 - Coquina "Bone Bed" (Autor: Márcio Sabbadini). c) Ponto 3 Afloramento Três Eras (Autor: Márcio Sabbadini). d) Ponto 4 - Paleoambiente Formação Pirambóia (Autor: Márcio Sabbadini). e) Ponto 5 - Stereosternum tumidum (COPE 1885), réptil primitivo presente na Formação Irati, Bacia do Paraná. Coletado na Pedreira Calcário Partezani. Sem número de coleção (col. partic.), 450 mm - LIMA (1989). f) Ponto 06 - Afloramento Pirambóia-Charqueada (Autor: Márcio Sabbadini).

- Ponto 2 - Afloramento Coquina (bone bed): apresenta a maior concentração e variação morfológica de material paleoictiológico da região de Rio Claro; segundo TOLEDO (2006), registra a maior concentração de placas dentárias de Dipnoiformes do Estado de São Paulo. Abriga, ainda, os primeiros fósseis de anfíbios assinalados na Formação Corumbataí.

- Ponto 3 - Afloramento das Três Eras: representa três estágios distintos de sedimentação na Bacia do Paraná: marinho de idade permiana, continental desértico de idade jurássica e o continental fluvial de idade cenozóica. Apresenta três grandes descontinuidades estratigráficas repre- 


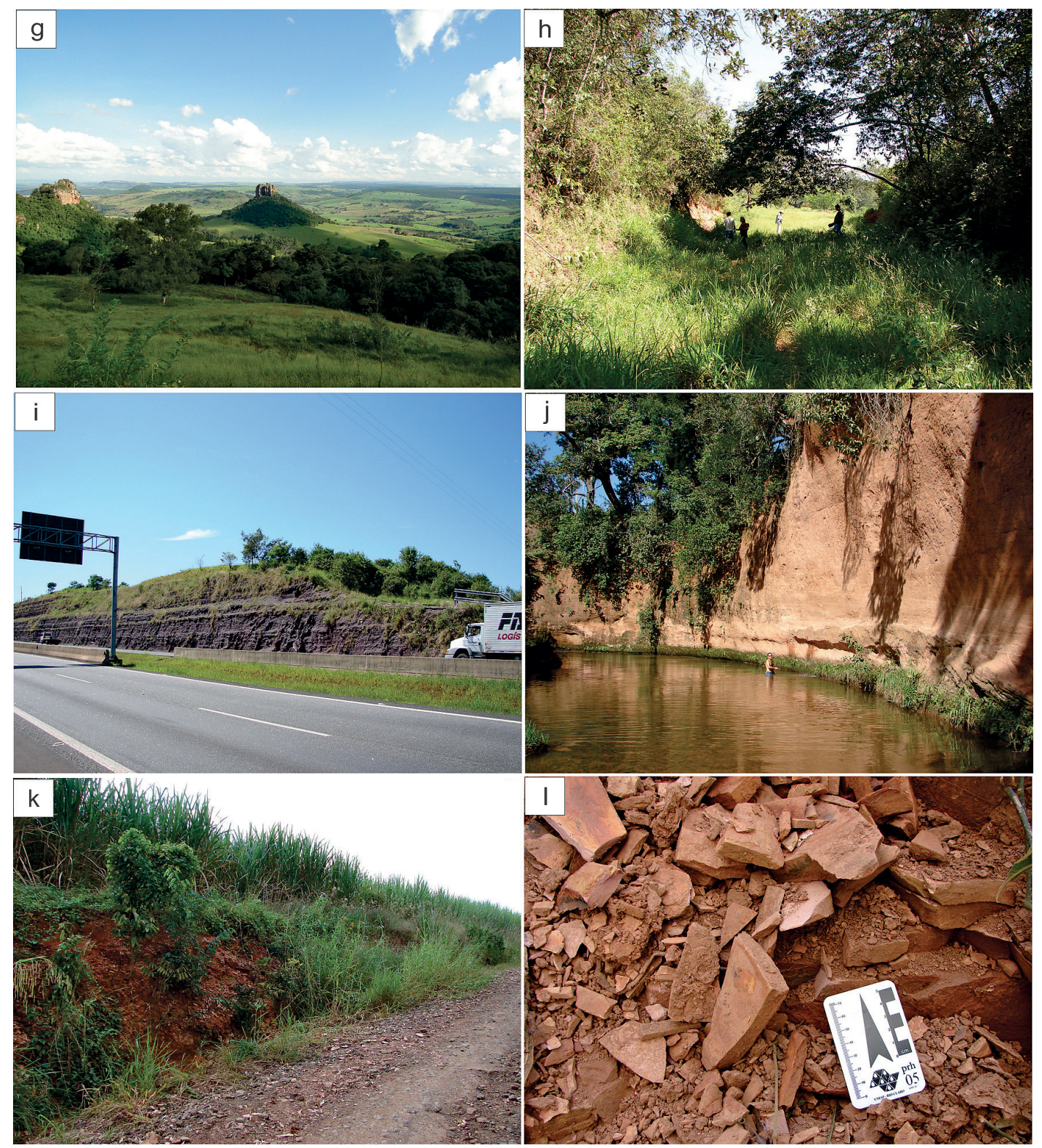

FIGURA 4 - Continuação da figura anterior. g) Ponto 7 - Vista panorâmica do Morro do Cuscuzeiro (Autor: Márcio Sabbadini. h) Ponto 8 - Afloramento Coquina de Camaquã (Autor: Rogério R. Ribeiro). i) Ponto 9 - Afloramento Bandeirantes (Autor: Márcio Sabbadini). j) Ponto 10 - Duna do Passa Cinco (Autor: Rogério R. Ribeiro). k) Ponto 11 - Clakercaris do Taquaral (Autor: Rogério R. Ribeiro). 1) Detalhe do ponto anterior (Autor: Rogério R. Ribeiro).

sentadas por superfícies irregulares que limitam as unidades litoestratigráficas.

- Ponto 4 - Paleoambiente Formação Pirambóia: constitui importante registro de paleodunas eólicas associadas a um ambiente desértico de idade jurássica.

- Ponto 5 - Pedreira Calcário Partezani: abriga um dos fósseis mais conhecidos da região de Rio Claro: o Stereosternum tumidum Cope, pequeno réptil da família dos mesossaurídeos. Esse vertebrado constitui o primeiro fóssil descrito para o território paulista. A importância desse réptil deve-se, entre outros motivos, ao fato da espécie M. tenuidens ter sido o único tetrápode a ser uti- 
TABELA 5 - Geossítios, unidades geológicas e geomorfológicas correspondentes, principal conteúdo, classificação hierárquica por pontuação obtida nos critérios $(\mathrm{A}, \mathrm{B}$ e C) e fase do processo de licenciamento minerário junto ao DNPM.

\begin{tabular}{|c|c|c|c|c|c|c|c|c|}
\hline Ponto & Geossitios & $\begin{array}{l}\text { Unidade } \\
\text { geológica } \\
\text { (PERROTA } \\
\text { et al. 2005) }\end{array}$ & $\begin{array}{c}\text { Unidade } \\
\text { geomorfológica } \\
\text { (ALMEIDA } \\
\text { 1964) }\end{array}$ & $\begin{array}{l}\text { Principal } \\
\text { conteúdo }\end{array}$ & $A$ & $B$ & $C$ & $\begin{array}{l}\text { Fase do } \\
\text { processo } \\
\text { licenciamento } \\
\text { minerário } \\
(D N P M)\end{array}$ \\
\hline 1 & $\begin{array}{c}\text { Afloramento } \\
\text { "Bivalves } \\
\text { Fepasa (Ferraz)" }\end{array}$ & $\begin{array}{l}\text { Formação } \\
\text { Corumbataí }\end{array}$ & $\begin{array}{l}\text { Depressão } \\
\text { Periférica }\end{array}$ & $\begin{array}{l}\text { Estratigráfico/ } \\
\text { Paleoambiental }\end{array}$ & $6^{\circ}$ & $7^{\circ}$ & $7^{\circ}$ & $\begin{array}{c}\text { Autorização de } \\
\text { Pesquisa }\end{array}$ \\
\hline 2 & $\begin{array}{l}\text { Afloramento } \\
\text { "Coquina (bone } \\
\text { bed)" }\end{array}$ & $\begin{array}{l}\text { Formação } \\
\text { Corumbataí }\end{array}$ & $\begin{array}{l}\text { Depressão } \\
\text { Periférica }\end{array}$ & $\begin{array}{l}\text { Estratigráfico/ } \\
\text { Paleoambiental/ } \\
\text { Paleontológico }\end{array}$ & $5^{\circ}$ & $3^{\circ}$ & $3^{\circ}$ & $\begin{array}{c}\text { Requerimento } \\
\text { de } \\
\text { Licenciamento }\end{array}$ \\
\hline 3 & $\begin{array}{l}\text { Afloramento } \\
\text { "Três Eras" }\end{array}$ & $\begin{array}{c}\text { Formações } \\
\text { Corumbataí, } \\
\text { Pirambóia e } \\
\text { Rio Claro }\end{array}$ & $\begin{array}{l}\text { Depressão } \\
\text { Periférica }\end{array}$ & $\begin{array}{l}\text { Estratigráfico/ } \\
\text { Paleoambiental }\end{array}$ & $8^{\circ}$ & $2^{\circ}$ & $5^{\circ}$ & $\begin{array}{c}\text { Autorização de } \\
\text { Pesquisa }\end{array}$ \\
\hline 4 & $\begin{array}{l}\text { Paleoambiente } \\
\text { "Formação } \\
\text { Pirambóia" }\end{array}$ & $\begin{array}{l}\text { Formação } \\
\text { Pirambóia }\end{array}$ & $\begin{array}{l}\text { Depressão } \\
\text { Periférica }\end{array}$ & Estratigráfico & $3^{\circ}$ & $10^{\circ}$ & $2^{\circ}$ & Área Livre \\
\hline 5 & $\begin{array}{c}\text { Pedreira } \\
\text { "Calcário } \\
\text { Partezani" } \\
\end{array}$ & $\begin{array}{l}\text { Formação } \\
\text { Iratí }\end{array}$ & $\begin{array}{l}\text { Depressão } \\
\text { Periférica }\end{array}$ & Paleontológico & $4^{\mathrm{o}}$ & $8^{\circ}$ & $11^{\circ}$ & $\begin{array}{l}\text { Concessão de } \\
\text { Lavra }\end{array}$ \\
\hline 6 & $\begin{array}{l}\text { Afloramento } \\
\text { "Pirambóia- } \\
\text { Charqueada" }\end{array}$ & $\begin{array}{l}\text { Formação } \\
\text { Pirambóia }\end{array}$ & $\begin{array}{l}\text { Depressão } \\
\text { Periférica }\end{array}$ & $\begin{array}{l}\text { Sedimentológico/ } \\
\text { Paleoambiental/ } \\
\text { Mineiro/ } \\
\text { Hidrogeológico }\end{array}$ & $1^{\mathrm{o}}$ & $6^{\circ}$ & $1^{\mathrm{o}}$ & $\begin{array}{c}\text { Requerimento } \\
\text { de Pesquisa }\end{array}$ \\
\hline 7 & $\begin{array}{l}\text { "Cuscuzeiro de } \\
\text { Analândia" }\end{array}$ & $\begin{array}{c}\text { Formação } \\
\text { Botucatu }\end{array}$ & $\begin{array}{c}\text { Cuestas } \\
\text { Basálticas }\end{array}$ & $\begin{array}{c}\text { Tectônico/ } \\
\text { Geomorfológico }\end{array}$ & $7^{\circ}$ & $11^{\circ}$ & $10^{\circ}$ & Área Livre \\
\hline 8 & $\begin{array}{l}\text { "Coquina de } \\
\text { Camaquã" }\end{array}$ & $\begin{array}{l}\text { Formação } \\
\text { Corumbataí }\end{array}$ & $\begin{array}{l}\text { Depressão } \\
\text { Periférica }\end{array}$ & $\begin{array}{c}\text { Estratigráfico/ } \\
\text { Sedimentológico/ } \\
\text { Paleoambiental/ } \\
\text { Paleontológico/ } \\
\text { Mineiro }\end{array}$ & $2^{\circ}$ & $5^{\circ}$ & $6^{\circ}$ & $\begin{array}{c}\text { Autorização de } \\
\text { Pesquisa }\end{array}$ \\
\hline 9 & $\begin{array}{l}\text { Afloramento } \\
\text { "Bandeirantes" }\end{array}$ & $\begin{array}{l}\text { Formação } \\
\text { Corumbataí } \\
\text { e Intrusivas } \\
\text { básicas } \\
\text { tabulares }\end{array}$ & $\begin{array}{l}\text { Depressão } \\
\text { Periférica }\end{array}$ & Mineiro & $9^{\circ}$ & $1^{\mathrm{o}}$ & $4^{\circ}$ & $\begin{array}{c}\text { Autorização de } \\
\text { Pesquisa }\end{array}$ \\
\hline 10 & $\begin{array}{c}\text { "Dunas do } \\
\text { Passa Cinco" }\end{array}$ & $\begin{array}{l}\text { Formação } \\
\text { Pirambóia }\end{array}$ & $\begin{array}{l}\text { Depressão } \\
\text { Periférica }\end{array}$ & $\begin{array}{l}\text { Paleoambiental/ } \\
\text { Hidrogeológico }\end{array}$ & $11^{\circ}$ & $9^{\circ}$ & $9^{\circ}$ & $\begin{array}{c}\text { Autorização de } \\
\text { Pesquisa }\end{array}$ \\
\hline 11 & $\begin{array}{c}\text { "Clakercaris do } \\
\text { Taquaral" }\end{array}$ & $\begin{array}{l}\text { Formação } \\
\text { Iratí } \\
\text { Membro } \\
\text { Taquaral }\end{array}$ & $\begin{array}{l}\text { Depressão } \\
\text { Periférica }\end{array}$ & Paleontológico & $10^{\circ}$ & $4^{\circ}$ & $8^{\circ}$ & $\begin{array}{l}\text { Requerimento } \\
\text { de Lavra }\end{array}$ \\
\hline
\end{tabular}

lizado pelos seguidores da deriva continental e da tectônica de placas para indicar uma conexão paleogeográfica entre América do Sul e África.

- Ponto 6 - Afloramento Pirambóia-Charqueada: guarda registros de paleoambientes continentais da Formação Pirambóia.

- Ponto 7 - Cuscuzeiro de Analândia: trata-se de um morro testemunho que registra a antiga topografia da área. É uma feição geomorfológica marcante, representativa dos processos de escul- turação do relevo paulista, no limite entre a Depressão Periférica e as Cuestas Basálticas.

- Ponto 8 - Coquina de Camaquã: neste afloramento, que expõe sedimentos do contato entre as formações Corumbataí e Pirambóia, ocorre uma concentração fossilífera gerada por eventos de tempestade. De acordo com informações dos professores Marcello G. Simões e Renato P. Ghilardi, a concentração fossilífera é "a mais bela coquina formada por conchas de moluscos bival- 
ves de todo o paleozoico da Bacia do Paraná".

- Ponto 9 - Afloramento Bandeirantes: geossítio representativo de ambiente marinho plataformal. Observa-se lateralmente a este afloramento a intrusão de um corpo hipoabissal de diabásio nas rochas da Formação Corumbataí.

- Ponto 10 - Afloramento Dunas do Passa Cinco: geossítio representativo de ambientes sedimentares desérticos antigos, com a ocorrência de pa- leodunas com estratificações cruzadas tabulares e acanaladas de grande porte (superior a $3 \mathrm{~m}$ ).

- Ponto 11 - Afloramento Clarkercaris do Taquaral: apresenta abundantes fósseis de crustáceos e de peixes. O gênero Clarkecaris foi descrito por MEZZALIRA (1952) com base em material procedente de jazigo fossilífero situado na rodovia Tatuí-Cesário Lange, Município de Tatuí.

TABELA 6 - Valores obtidos pelos geossítios nos critérios A, B e C.

\begin{tabular}{|c|c|c|c|c|c|c|c|c|c|c|c|}
\hline \multirow[b]{2}{*}{ Critérios } & \multicolumn{11}{|c|}{ GEOSSÍTIOS } \\
\hline & 1 & 2 & 3 & 4 & 5 & 6 & 7 & 8 & 9 & 10 & 11 \\
\hline$A 1$ & 5 & 5 & 5 & 5 & 5 & 5 & 3 & 5 & 1 & 1 & 4 \\
\hline$A 2$ & 1 & 2 & 2 & 2 & 4 & 2 & 4 & 2 & 1 & 2 & 1 \\
\hline$A 3$ & 4 & 4 & 3 & 3 & 4 & 4 & 3 & 4 & 3 & 1 & 4 \\
\hline$A 4$ & 3 & 2 & 2 & 5 & 3 & 3 & 3 & 5 & 2 & 5 & 3 \\
\hline$A 5$ & 4 & 4 & 3 & 3 & 3 & 5 & 3 & 5 & 5 & 5 & 4 \\
\hline$A 6$ & 5 & 5 & 5 & 5 & 5 & 5 & 5 & 3 & 5 & 3 & 1 \\
\hline$A 7$ & 1 & 1 & 1 & 1 & 1 & 1 & 1 & 1 & 1 & 1 & 1 \\
\hline$A 8$ & 1 & 1 & 1 & 1 & 1 & 1 & 1 & 1 & 1 & 1 & 1 \\
\hline$A 9$ & 3 & 3 & 3 & 3 & 2 & 4 & 4 & 4 & 5 & 4 & 4 \\
\hline Total A & 27 & 27 & 25 & 28 & 28 & 30 & 27 & 30 & 24 & 23 & 23 \\
\hline$B 1$ & 5 & 5 & 5 & 5 & 5 & 5 & 5 & 5 & 5 & 5 & 5 \\
\hline$B 2$ & 3 & 3 & 3 & 3 & 3 & 3 & 3 & 3 & 3 & 5 & 3 \\
\hline$B 3$ & 1 & 2 & 3 & 3 & 2 & 2 & 2 & 3 & 4 & 2 & 3 \\
\hline$B 4$ & 3 & 4 & 4 & 4 & 2 & 4 & 3 & 2 & 4 & 3 & 3 \\
\hline$B 5$ & 5 & 5 & 5 & 5 & 5 & 5 & 5 & 5 & 5 & 5 & 5 \\
\hline$B 6$ & 3 & 3 & 3 & 1 & 3 & 1 & 1 & 3 & 3 & 1 & 3 \\
\hline$B 7$ & 5 & 5 & 5 & 3 & 5 & 5 & 2 & 5 & 5 & 3 & 5 \\
\hline Total B & 25 & 27 & 28 & 24 & 25 & 25 & 21 & 26 & 29 & 24 & 27 \\
\hline$C 1$ & 1 & 1 & 1 & 1 & 1 & 1 & 1 & 1 & 1 & 1 & 3 \\
\hline$C 2$ & 2 & 5 & 2 & 5 & 3 & 5 & 1 & 2 & 5 & 1 & 2 \\
\hline$C 3$ & 4 & 5 & 5 & 5 & 1 & 5 & 5 & 4 & 5 & 5 & 2 \\
\hline$C 4$ & 5 & 4 & 4 & 5 & 5 & 5 & 5 & 5 & 4 & 5 & 5 \\
\hline$C 5$ & 2 & 3 & 3 & 5 & 2 & 5 & 1 & 2 & 3 & 2 & 2 \\
\hline C6 & 1 & 1 & 1 & 1 & 1 & 1 & 1 & 1 & 1 & 1 & 1 \\
\hline Total C & 15 & 19 & 16 & 22 & 13 & 22 & 14 & 15 & 19 & 15 & 15 \\
\hline
\end{tabular}

As tabelas 7 e 8 apresentam, respectivamente, a ocorrência dos critérios A, B e C, nos geossítios e o potencial de uso (atividades) (A-Alto, M-Médio e B-Baixo).

4.2 Avaliação e hierarquização dos geossítios quanto à importância Local/ Regional e Nacional/ Internacional.

4.2.1 Relevância no âmbito local e prioridade nas ações de geoconservação

Aplicando a metodologia de avaliação adaptada de BRILHA (2005), por meio da equação $\mathrm{Q}=(\mathrm{A}+\mathrm{B}+\mathrm{C}) / 3$, obteve-se uma hierarquização dos geossítios quanto à relevância local/regional e à necessidade de proteção (Figura 5 e Tabela 6).

4.2.2 Relevância no âmbito Nacional/Internacional e prioridade nas ações de geoconservação

Aplicando a metodologia de avaliação adaptada de BRILHA (2005), por meio da equação $\mathrm{Q}=$ $(2 \mathrm{~A}+\mathrm{B}+1.5 \mathrm{C}) / 3$, obteve-se uma hierarquização dos geossítios quanto à relevância nacional/internacional e à necessidade de proteção. Dos onze geossítios identificados, apenas quatro têm potencial para serem geossítios de âmbito internacional/ nacional (Figura 6). 
TABELA 7 - Ocorrência dos critérios A, B e C nos geossítios identificados.

\begin{tabular}{|c|c|c|}
\hline Critérios & Características & $\begin{array}{l}\text { Geossitios } \\
\text { (ocorrência) }\end{array}$ \\
\hline A1 & Raros na área em estudo & $63 \%$ \\
\hline A2 & Extensão de 1.000 a $10.000 \mathrm{~m}^{2}$ & $81 \%$ \\
\hline A3 & $\begin{array}{c}\text { Possui pelo menos uma tese ou dissertação mestrado ou mais de um artigo publicado em revista } \\
\text { internacional ou mais de cinco artigos publicados em revistas nacionais }\end{array}$ & $54 \%$ \\
\hline A4 & $\begin{array}{c}\text { Ilustram basicamente produtos e processos geológicos, de maneira clara e expressiva, ao público } \\
\text { com algum conhecimento geológico }\end{array}$ & $72 \%$ \\
\hline A5 & Possui no mínimo quatro conteúdos de interesse & $63 \%$ \\
\hline A6 & São locais-tipo & $72 \%$ \\
\hline A7 & Não ocorrem associados a elementos do patrimônio cultural & $100 \%$ \\
\hline A8 & Não ocorrem associados a outros elementos do meio natural & $100 \%$ \\
\hline A9 & $\begin{array}{l}\text { a) Perfeitamente conservados, sem evidências de deterioração. } \\
\text { b) Apresentam alterações, mas que não impedem a observação das suas características essenciais } \\
\text { c) apresentam alguma deterioração }\end{array}$ & $\begin{array}{l}09 \% \\
36 \% \\
45 \%\end{array}$ \\
\hline B1 & $\begin{array}{c}\text { Apresenta viabilidade para o desenvolvimento de atividades científicas, pedagógicas, } \\
\text { turísticas e recreativas: }\end{array}$ & $100 \%$ \\
\hline B2 & Possui elementos exógenos que dificultam a observação de alguns conteúdos do geossítio & $90 \%$ \\
\hline B3 & $\begin{array}{l}\text { a) É possível a coleta de minerais ou rochas ou fósseis sem a perda da integridade do geossítio } \\
\text { b) É possível a coleta de algum tipo de objeto, embora com restrições. } \\
\text { c) É possível a coleta de algum tipo de objeto, embora comprometa a integridade do geossítio }\end{array}$ & $\begin{array}{l}10 \% \\
36 \% \\
45 \%\end{array}$ \\
\hline B4 & É possível o acesso por carro & $80 \%$ \\
\hline B5 & Possui alojamento e restaurante para grupos de 50 pessoas a menos de $15 \mathrm{~km}$ & $100 \%$ \\
\hline B6 & Possui entre 150.000 e 500.000 habitantes em um raio de $25 \mathrm{~km}$. & $63 \%$ \\
\hline B7 & Ocorrem em municípios com elevados índices de riqueza e bons indicadores sociais. & $72 \%$ \\
\hline $\mathrm{C} 1$ & $\begin{array}{l}\text { Geossítio situado a menos de } 500 \mathrm{~m} \text { de uma atividade potencialmente degradadora (minerações, } \\
\text { instalações industriais, áreas recreativas, estruturas rodo e ferroviárias, áreas urbanas, etc.) }\end{array}$ & $81 \%$ \\
\hline $\mathrm{C} 2$ & Situa-se em área sem regime de proteção e sem controle de acesso & $36 \%$ \\
\hline $\mathrm{C} 3$ & Encontra-se em uma zona sem nenhum tipo de interesse mineiro (Área Livre) & $63 \%$ \\
\hline $\mathrm{C} 4$ & Apresenta valor de terreno $<\mathrm{R} \$ 5,00$ por $\mathrm{m}^{2}$ & $72 \%$ \\
\hline $\mathrm{C} 5$ & $\begin{array}{l}\text { a) Situa-se em terreno predominantemente pertencente ao Estado } \\
\text { b) Situa-se em terreno parcialmente público e privado } \\
\text { c) Situa-se em terreno privado pertencente a um só proprietário }\end{array}$ & $\begin{array}{l}18 \% \\
27 \% \\
45 \%\end{array}$ \\
\hline C6 & Apresenta possibilidade de deterioração de todos os conteúdos por atividade antrópica ou natural. & $100 \%$ \\
\hline
\end{tabular}

TABELA 8 - Potencial de uso e de conteúdo de interesse dos geossítios (A-Alto; M-Médio e B-Baixo).

\begin{tabular}{|c|c|c|c|c|c|c|c|c|c|c|c|c|}
\hline \multirow[b]{2}{*}{ Atividade } & \multicolumn{12}{|c|}{ Geossitio } \\
\hline & 1 & 2 & 3 & 4 & 5 & 6 & 7 & 8 & 9 & 10 & 11 & $\begin{array}{c}\text { Total } \\
\text { geossitios }\end{array}$ \\
\hline Cientifica & A & A & A & A & A & A & A & A & A & $\mathrm{B}$ & A & $100 \%$ \\
\hline Pedagógica & A & M & M & M & M & A & A & A & B & B & A & $100 \%$ \\
\hline Turística & M & $\mathrm{B}$ & $\mathrm{B}$ & $\mathrm{B}$ & M & B & A & $\mathrm{B}$ & $\mathrm{B}$ & M & B & $100 \%$ \\
\hline Econômica & - & - & - & - & - & A & - & M & A & B & - & $36 \%$ \\
\hline \multicolumn{13}{|c|}{ Conteúdos de Interesse } \\
\hline Estratigráfico & A & A & A & A & M & M & - & A & M & M & M & $91 \%$ \\
\hline Sedimentológico & M & M & M & M & - & A & M & A & M & M & M & $91 \%$ \\
\hline Paleoambiental & A & A & A & B & M & A & - & A & M & A & M & $91 \%$ \\
\hline Paleontológico & A & A & - & - & A & - & - & A & - & - & $\mathrm{A}$ & $41 \%$ \\
\hline Tectônico & - & - & - & - & - & - & A & - & M & B & - & $27 \%$ \\
\hline Geomorfológico & - & - & - & - & - & - & A & - & - & $\mathrm{M}$ & M & $27 \%$ \\
\hline Mineiro & - & - & - & - & - & A & - & A & A & - & - & $27 \%$ \\
\hline Hidrogeológico & - & - & - & - & - & A & - & - & - & A & - & $18 \%$ \\
\hline
\end{tabular}




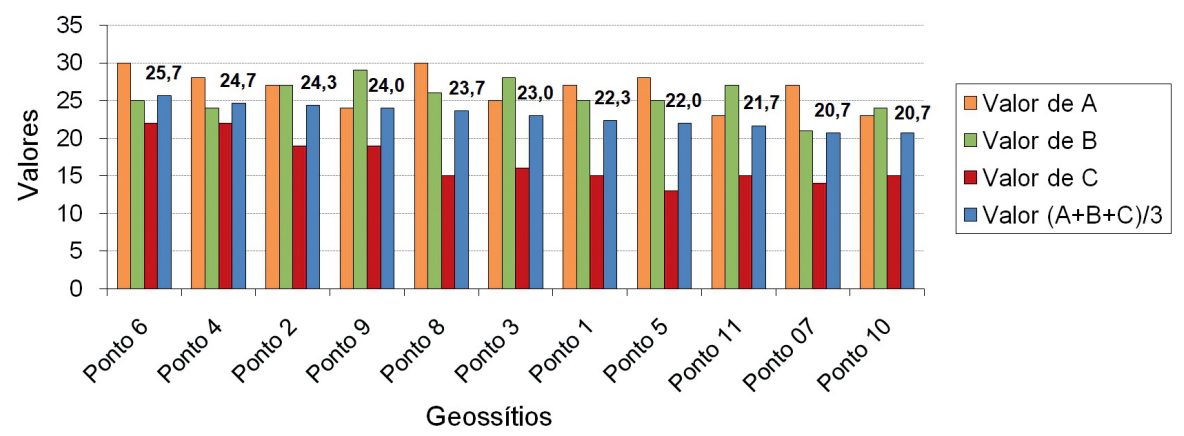

FIGURA 5 - Hierarquização dos geossítios quanto à relevância local/regional e à necessidade de proteção.

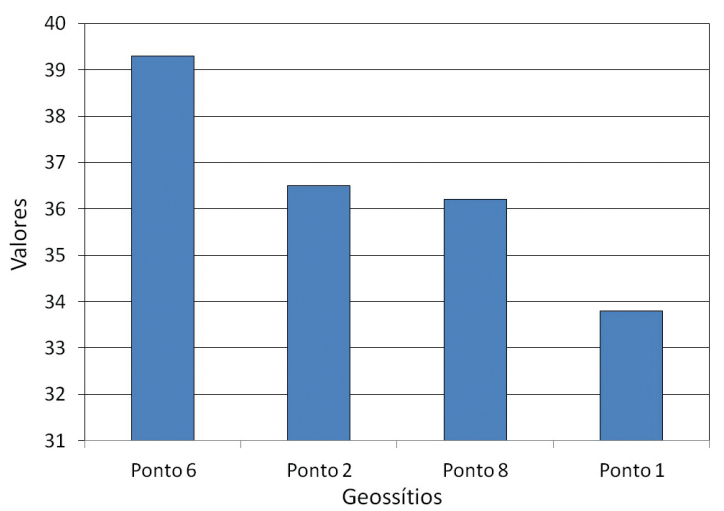

FIGURA 6 - Hierarquização dos geossítios quanto à relevância Internacional/Nacional e à necessidade de proteção.

\section{DISCUSSÕES}

Apesar de até o momento não existir uma estratégia de sistematização do patrimônio geológico nos níveis estadual e nacional, os métodos utilizados para o inventário e avaliação - adaptados às condições geográficas da área de estudo - foram úteis para hierarquizar os geossítios quanto a sua relevância, bem como orientar a elaboração de uma estratégia de conservação desse patrimônio natural, que hoje se encontra ameaçado.

A seguir, são analisados aspectos relacionados à abordagem metodológica utilizada e os resultados obtidos.

\subsection{Abordagem metodológica}

\subsubsection{Inventário}

A inexistência de uma proposta de sistematização de inventário do patrimônio geológico que resgate a história geológica do Estado de São Paulo, organizada e caracterizada em contextos geológicos, dificultou o processo de inventário e avaliação na área de estudo. Segundo LIMA (2008), os contextos geológicos ou frameworks (representativos das províncias geológicas estaduais) são ferramentas úteis para o inventário de grandes territórios, uma vez que facilita e focaliza os esforços para a identificação dos geossítios com valor científico (de forma não isolada), em detrimento dos outros tipos de valores. Os contextos geológicos podem ser definidos tendo como base, por exemplo, aspectos geomorfológicos, tectônicos, metalogenéticos, entre outros.

Tal deficiência é recorrente em nível nacional e se deve principalmente pela carência de bases legais que garantam a conservação do patrimônio geológico (LIMA 2008). A mesma autora apresentou uma proposta para a sistematização do inventário do patrimônio geológico brasileiro. Esta proposta, a ser adotada voluntariamente pelos estados, requer destes entes federativos os seguintes passos: a) definição do objetivo do inventário; b) organização de grupos de trabalho; c) revisão bibliográfica; d) identificação dos contextos geológicos; e) caracterização dos contextos geológicos; f) identificação dos geossítios para cada contexto geológico e, finalmente, g) caracterização dos geossítios.

O uso combinado das abordagens metodológicas de WIMBLEDOM et al. (1999) e SHARPLES (2002) para o inventário de reconhecimento, adotado nesse trabalho, apresenta algumas desvantagens. Segundo CARCAVILLA URQUI et al. (2007), o inventário de reconhecimento proposto por SHARPLES "serve para focar a atenção na existência de uma série de lugares de alto valor e para promover a conservação dos elementos mais excepcionais, e não visa a representatividade do meio geológico da 
área em estudo". Apesar de não contemplar a história geológica da área de estudo, um inventário de reconhecimento tem como vantagem uma adesão praticamente definitiva desses geossítios ao patrimônio geológico da região.

Dessa forma, o inventário realizado neste trabalho vem somar ao iniciado por ZAINE \& PERINOTTO (1996). Esses autores realizaram uma abordagem descritiva e científica de boa parte do patrimônio geológico da área de estudo, trazendo considerações sobre o potencial turístico da área e propostas de educação ambiental, de modo a mobilizar órgãos públicos municipais e estaduais, a comunidade (principalmente através da rede de ensino) e as entidades privadas. Complementam, ainda, afirmando que esse potencial e o desenvolvimento de pesquisa na área podem constituir um impulso ao crescimento econômico, desde que respeitem as limitações de zoneamento expressas nas Áreas de Proteção Ambiental (APA's) existentes e que contribuam para o desenvolvimento sustentado da região da Bacia do Corumbataí.

\subsubsection{Avaliação}

PEREIRA (2010) mostra que as propostas pré-existentes de metodologias para a avaliação do patrimônio geológico e geomorfológico foram elaboradas dentro de uma realidade europeia, sendo a grande maioria desenvolvida para uma abordagem local, enquanto apenas duas (BRILHA 2005 e GARCIA-CORTÉS \& CARCAVILLA URQUI 2009) foram direcionadas para uma aplicação mais universal.

Mesmo com um caráter mais universal, alguns critérios e valores da metodologia de BRILHA (2005) necessitaram ser adaptados, face às características sócio-econômico-ambientais da área de estudo.

As adaptações nas metodologias de avaliação à realidade do espaço em estudo é comum e já foram observadas em outros trabalhos de inventário no Brasil, especialmente no Estado da Bahia, no projeto de geoconservação e de desenvolvimento sustentável na Chapada Diamantina (PEREIRA 2010). Este autor observou a necessidade da adaptação das metodologias europeias à realidade geográfica da região central do Brasil, considerando-se as condições intrínsecas e as especificidades dos geossítios inventariados. Desenvolveu uma metodologia que teve como ponto de partida propostas pré-existentes (com um conjunto de parâmetros comuns a todas elas, que consistem em aspectos relevantes na avaliação do patrimônio geológico) e finaliza inserindo alguns parâmetros novos, totalizando, ao final, um conjunto de 20 parâmetros.

Segundo CARCAVILLA URQUI et al. (2007) tais adaptações são imprescindíveis, uma vez que são muito poucos os estudos que explicam de forma detalhada os critérios para calcular o valor intrínseco dos pontos e é difícil estabelecer parâmetros gerais que se ajustem a todos os inventários. Conforme os autores "o mais importante sobre essas propostas é definir um amplo número de fatores que, em cada caso, cumpram os objetivos do estudo, selecionando aqueles que são mais úteis".

Não há, portanto, um método de avaliação de geossítios de uso imediato. Deve-se privilegiar os recursos disponíveis (informação, tempo, pessoal e orçamento) e os objetivos do inventário (CARCAVILLA URQUI et al. 2007).

Outro importante problema na adoção de métodos para avaliação é o grau de subjetividade da equipe técnica na realização dos trabalhos. Observou-se no presente estudo que alguns critérios e valores apresentam certa margem de discricionariedade e/ou ambiguidade na sua aplicação por parte dos técnicos. Nessa situação é importante que a avaliação realizada por uma equipe técnica não seja muito destoante daquelas executadas por outras equipes.

Para diminuir o grau de subjetividade, é necessário adotar critérios e definir níveis de qualidade (ou de importância) para valorar geossítios, de maneira a não depender de um especialista da área (UCEDA 2000). O autor sugere o emprego de procedimentos do tipo multicritério, que aplicam métodos aritméticos para estabelecer hierarquias. Essas ferramentas foram empregadas na área de estudo, permitindo estabelecer uma hierarquia de valores entre os geossítios, com indicadores de qualidade de 1 a 5. Os resultados obtidos mostram coerência e consistência e, de maneira geral, refletem a realidade evidenciada de maneira qualitativa em campo.

\subsection{Critérios adotados na classificação dos geossítios}

5.2.1 Valores intrínsecos dos geossítios (Critério A)

Os geossítios identificados apresentam alto valor científico, distribuído pelos seguintes conteúdos: estratigráfico, geomorfológico, hidrogeológico, mineiro, paleoambiental, paleontológico, sedimentológico e tectônico.

Nesses geossítios são encontradas feições geológicas cujo valores científicos e didáticos vêm 
sendo estudados há décadas por pesquisadores de instituições de ensino do Estado de São Paulo, além de fazerem parte de roteiros de aulas de campo para muitas disciplinas dos cursos de Geologia e áreas afins.

Os geossítios 1, 2, 5, 8 e 11 (Figura 4 e Tabela 5) apresentam significativo conteúdo paleontológico (ricos em fósseis de bivalves, crustáceos e répteis), e foram estudados com detalhe por diversos autores, permitindo, assim, a elaboração de importantes teorias sobre a evolução paleoambiental da Bacia do Paraná.

Todos os 11 pontos identificados apresentam representatividade regional em relação às unidades litoestratigráficas a que pertencem, além de registrarem parte da história geológica da região de Rio Claro. Embora ocorram muitos outros afloramentos na área de estudo, tais pontos destacam-se pelas boas exposições com continuidade lateral, acesso razoável, características geológicas raras (que servem de modelos didáticos e educacionais) e potencial de entendimento da evolução geológica ao público com algum conhecimento sobre o tema.

Em relação aos pontos de beleza cênica, destacam-se o Morro do Cuscuzeiro e as Dunas do Rio Passa Cinco (Pontos 7 e 10), que também apresentam elementos de interesse tectônico e geomorfológico de interesse para a evolução geológico/ geomorfológica da área.

\subsubsection{Uso Potencial (Critério B)}

Os geossítios apresentam, além do conteúdo científico, outros usos potenciais como o didático, econômico e turístico (Tabela 8). De todos os usos possíveis, o turístico é o que apresenta menor potencial. Mesmo que esse patrimônio se encontre em uma região com bons índices econômicos e elevados indicadores sociais, assim como facilidade de acesso, os resultados indicaram médio a baixo potencial turístico.

Os pontos 2, 3, 4, 6, 8, 9 e 11 apresentaram, segundo os critérios analisados, baixo potencial turístico. Entretanto, ressalta-se que os pontos 2, 4, 6, e 9 encontram-se, atualmente, às margens de rodovias e os pontos 1 e 3 , às margens de ferrovias, o que pode ser um fator positivo. Caso haja uma estratégia de recepção adequada ao turista junto a essas vias de tarnsporte, seu potencial turístico pode melhorar muito. Conforme UCEDA (2000) "as estradas e as rodovias são lugares de grande visibilidade, alto fluxo de pessoas e acesso imediato, em geral com excelentes condições de observação. (...) se conseguirmos que em toda uma série de pontos de interesse ao longo da rede de rodovias e de estradas seja estabelecido um conjunto de lugares com condições para a observação de sítios geológicos de interesse, com áreas de parada e descanso, boa sinalização prévias ao longo da rota e painéis explicativos, se terá dado um passo muito importante para impulsionar a proteção do patrimônio geológico e para a divulgação e conhecimento público dos temas geológicos".

A atividade turística associada a geossítios, quando devidamente planejada e manejada, pode ser uma forte aliada na conservação do patrimônio natural, especialmente quando há agregação de valor para o proprietário, gerando renda com algum desenvolvimento econômico sustentável.

Embora os critérios aplicados não apresentem limitações à atividade turística, somente o ponto 7 (Cuscuzeiro de Analândia) apresentou alto potencial turístico. Isso se deve ao fato deste geossítio apresentar grande beleza cênica, além de potencial científico, pedagógico e até econômico. Seus atributos bióticos e abióticos são favoráveis para a criação de uma unidade de conservação (UC), conforme disposto na Lei Federal $n^{\circ}$ 9.985/2000, seja no Grupo das UC's de Uso Sustentável (p. ex. Reserva Particular do Patrimônio Natural - RPPN; Área de Relevante Interesse Ecológico), ou no Grupo das UC's de Proteção Integral (por exemplo, Monumento Natural).

Em relação aos pontos 1, 5, 10, foi atribuído um médio potencial turístico (uso secundário), mas não inadequado. $\mathrm{O}$ fator preocupante para esses pontos é que são vulneráveis à atividade minerária; o ponto 5 já está em processo de concessão de lavra, inclusive com uma mina ativa (Tabela 5).

Possuir um patrimônio geológico de valor científico não significa auferir ganhos econômicos imediatos com o turismo. É necessária a elaboração de uma estratégia adequada de valorização e de divulgação desse patrimônio, capaz de impulsionar este mercado.

\subsubsection{Necessidade de proteção (Critério C)}

Os geossítios encontram-se, ainda, sob influência de ameaças já apontadas por ZAINE \& PERINOTTO (1996), entre elas: cultivo da cana-de-açúcar, desmatamento em cabeceiras, queimadas, aceleração dos processos erosivos, ocorrência de escavações e pilhas de rejeito (mineração) e alterações nas margens dos rios e ocupação das Áreas de Preservação Permanente (APP). Além disso, fo- 
ram apuradas no presente trabalho: falta de controle de acesso ao patrimônio, retirada descontrolada de amostras, prática de atividades agropecuárias (pastagem, queimadas, compactação do solo por pisoteio do gado, trânsito de máquinas agrícolas), avanço da cobertura vegetal, ampliação do leito de estradas, rodovias e ferrovias, entre outras.

Quatro ameaças foram identificadas em campo e melhor estudadas: exploração mineral (C3); proximidade a zonas potencialmente degradadoras (C1); regime de proteção ou proteção incidente (C2) e vulnerabilidade (C6).

\section{a) Exploração mineral}

$\mathrm{Na}$ área de estudo, todos os 11 pontos estudados apresentam potencial como fonte de matériaprima mineral.

A exploração mineral representa uma atividade muito importante para os municípios envolvidos, bem como para o desenvolvimento do Estado de São Paulo. Destacam-se entre as atividades minerárias a exploração de argilitos da Formação Corumbataí (fonte para a indústria cerâmica de revestimento), calcários pirobetuminosos da Formação Iratí (fonte de corretivo agrícola) e arenitos da Formação Pirambóia (indústria de vidro e fundição).

Em consulta ao DNPM (Departamento Nacional de Pesquisa Mineral), os pontos que estão em áreas objeto de análise em processos minerários são: $1,2,3,5,6,8,9,10,11$. Os pontos 4 e 7 situam-se em áreas livres ou sem processo de requerimento de pesquisa (Tabela 5).

Apesar dos pontos 2, 3, 4, 6, 9 e 10 estarem em áreas sob análise técnica do DNPM, eles situam-se às margens de rodovias, ferrovias e de cursos d' água. Essas áreas marginais geralmente correspondem às áreas de segurança das Rodovias e Ferrovias (Pontos 2, 3, 4, 6 e 9), ou às Áreas de Proteção Permanente (APP) de cursos d' água (Ponto 10). Dessa forma, esses geossítios encontram-se atualmente menos vulneráveis à atividade mineral, face às restrições de origem legal existentes. Entretanto, os pontos 2, 3, 4, 6 e 9 passam a se encontrar em situação vulnerável, quando do planejamento futuro para ações de ampliação dessas ferrovias/rodovias.

Os geossítios mais ameaçados são os pontos 11 (fase de Requerimento de Lavra) e o ponto 5 (Lavra já autorizada).

b) Proximidade a zonas potencialmente degradadoras
Destacam-se as atividades agropastoris, como o plantio de cana de açúcar e a pecuária, e o desenvolvimento de processos erosivos. Estas atividades ocorrem principalmente na área de entorno da maioria dos geossítios e, em alguns casos, diretamente sobre os mesmos.

c) Regime de proteção ou proteção incidente

A maioria dos pontos estudados encontra-se em propriedades rurais particulares ou em áreas de concessão de rodovias e ferrovias. O acesso a estas áreas é facilitado pela ausência de proteção.

A área de estudo apresenta cinco unidades de conservação importantes, sendo quatro delas da categoria de Uso Sustentável (APA Corumbataí Botucatu-Tejupá - Perímetro Corumbataí; APA Piracicaba-Juqueri Mirim-Área 1; Estação Experimental de Itirapina e a Floresta Estadual Edmundo Navarro de Andrade) e uma na categoria de Proteção Integral (Estação Ecológica de Itirapina). Os pontos $1,3,5,6,8,10$ e 11 encontram-se dentro da APA Piracicaba Juqueri Mirim-Área 1.

Um dos instrumentos que poderão ser utilizados para auxiliar na elaboração das estratégias de conservação dos geossítios são os Conselhos Gestores das Áreas de Proteção Ambiental (APA's), criados pela Lei Federal no 9.985/2000 (Sistema Nacional de Unidades de Conservação - SNUC). Essas unidades de conservação de uso sustentável possuem esse importante fórum para discutir a forma de gestão dos bens bióticos (biodiversidade) e abióticos (geodiversidade) existentes nestes territórios.

\section{d) Vulnerabilidade dos geossítios}

Em relação à vulnerabilidade dos pontos levantados (possibilidade de deterioração por atividade antrópica ou natural), todos se apresentam vulneráveis, especialmente, os pontos localizados às margens das rodovias e ferrovias (pontos 2, 3, 4, 6 e 9). Além da expansão das estradas, a pecuária e o desmatamento contribuem para a vulnerabilidade destes locais.

\subsection{Avaliação e hierarquização dos geossítios}

Apesar de todos os onze geossítios apresentarem valores totais muito próximos para os critérios analisados (A, B e C), somente os pontos 1, 2, 6 e 8 conseguiram somar pontos suficientes para se enquadrarem em geossítios com potencial para serem de âmbito nacional/internacional. 
O principal critério para que esses geossítios obtenham uma boa posição em qualquer nível de inventário é o grau de conhecimento científico. Este critério, baseado no número e no tipo de publicações, é utilizado em várias metodologias adotadas para o inventário do patrimônio geológico (CARCAVILLA URQUI et al. 2007, CENDRERO 1996, ALCALÁ 2000 apud CARCAVILLA URQUI et al. 2007). Segundo BRILHA (2005), esse critério "reflete, de alguma forma, o grau de importância que lhe é atribuído pela comunidade acadêmica".

Além da raridade, reconhecimento como local-tipo e o não comprometimento por ameaças diversas, esses geossítios possuem pelo menos uma tese de doutorado ou dissertação de mestrado, ou mais de um artigo publicado em revista internacional ou mais de cinco artigos em revista nacionais. Ou seja, na área de estudo, o critério A3 foi decisivo para que os geossítios elevassem de categoria.

Esses geossítios devem ter prioridade no recebimento de recursos para sua conservação, independentemente do uso que possa ser implementado.

\section{CONCLUSÕES}

Os onze geossítios identificados e descritos para a região de Rio Claro possuem alto valor científico (paleontológico, geológico e geomorfológico), amplo uso potencial (científico, educacional, econômico e turístico), além de quatro deles apresentarem valores que permitem serem incorporados aos inventários dos patrimônios geológicos nacional e internacional.

Entretanto, este patrimônio geológico encontra-se ainda sob ameaça e abandono, requerendo uma estratégia de conservação que promova ações voltadas à pesquisa, conservação e divulgação do mesmo, ratificando as premissas da Convenção do Patrimônio Natural e Cultural Mundial apresentadas pela UNESCO em 1972.

A inexistência de uma proposta para a sistematização do inventário do patrimônio geológico estadual ou nacional, que resgate a história geológica da área estudada, dificulta os trabalhos de inventário e de avaliação propostos para a região de Rio Claro.

Apesar disso, enquanto não há essa sistematização, os métodos utilizados para inventário e avaliação (WIMBLEDON et al. 1999, SHARPLES 2002, BRILHA 2005), quando adaptados às características sócio-econômico-ambientais da área de estudo, mostraram-se aplicáveis, uma vez que con- tribuem para a implantação de uma estratégia de conservação, reduzem a subjetividade do processo e indicam a prioridade de investimento de recursos na conservação desse patrimônio geológico.

O inventário, e principalmente sua quantificação, não esgotam o potencial geológico da região de Rio Claro, cabendo a continuidade do levantamento desse patrimônio em novos projetos de pesquisa. Ressalta-se que essas etapas são dinâmicas, especialmente quando há inclusão de novos geossítios ou destituição de alguns já inventariados, uma vez que as ameaças atuam diretamente na valoração dos critérios.

\section{AGRADECIMENTOS}

Agradecemos o ilustre apoio dos professores e especialistas Dra. Rosemarie Rohn Davies e Dr. Reinaldo José Bertini, da UNESP de Rio Claro, pelas informações disponibilizadas para os geossítios identificados. Ao Instituto Geológico, pelo financiamento da pesquisa. Ao apoio dos pesquisadores e professores do Instituto Florestal (SMA), UNICAMP e UNESP. Aos senhores Roberval Mariano, Márcio Félix Dionísio, Valentim O. dos Santos e Márcio Sabbadini, pelo apoio na realização deste projeto, e aos relatores e editores da Revista do IG, pelas contribuições na elaboração deste artigo.

\section{REFERÊNCIAS BIBLIOGRÁFICAS}

ALMEIDA, F.F.M. 1964. Fundamentos geológicos do relevo paulista. Boletim do Instituto Geográfico e Geológico, 41: 169-263.

BRASIL. 1966. Decreto $\mathrm{n}^{\circ} 58.054$, de 23 de março de 1966. Brasília. Promulga a convenção para a proteção da flora, fauna e das belezas cênicas dos países da América. Brasília, Senado Federal. Subsecretaria de Informações.

BRASIL. 1967. Decreto-Lei n ${ }^{\circ} 27$, de 28 de fevereiro de 1967. Brasília. Dá nova redação ao Decreto-Lei $\mathrm{n}^{\circ} 1.985$ (Código de Minas) de 29 de janeiro de 1940. Brasília, Ministério de Minas e Energia.

BRASIL. 1977. Decreto ${ }^{\circ} 80.978$, de 12 de dezembro de 1977. Brasília. Promulga a convenção relativa à proteção do Patrimônio Mundial, Cultural e Natural, de 1972. Brasília, Ministério de Minas e Energia. 
BRASIL. 1997. Resolução CONAMA n 237, de 19 de dezembro de 1997. Brasília. Ministério do Meio Ambiente. Conselho Nacional de Meio Ambiente.

BRASIL. 2000. Lei $\mathrm{n}^{\circ}$ 9985, de 18 de julho de 2000. Institui o Sistema Nacional de Unidades de Conservação da Natureza, e dá outras providências. Brasília. Ministério do Meio Ambiente.

BRASIL. 2012. Lei $\mathrm{n}^{\circ} 12.651$, de 25 de maio de 2012. Dispõe sobre a proteção da vegetação nativa; altera as Leis nos 6.938 , de 31 de agosto de 1981, 9.393, de 19 de dezembro de 1996, e 11.428, de 22 de dezembro de 2006; revoga as Leis nos 4.771, de 15 de setembro de 1965, e 7.754, de 14 de abril de 1989, e a Medida Provisória no 2.166-67, de 24 de agosto de 2001; e dá outras providências. Brasília. Ministério do Meio Ambiente.

BRILHA, J. 2005. Patrimônio geológico e geoconservação: a conservação da natureza na sua vertente geológica. Palimage Editores, Braga, $190 \mathrm{p}$.

CARCAVILLA URQUI, L.; LÓPEZ-MARTINEZ, J.; DURÁN VALSERO J.J. 2007. Patrimonio geológico y geodiversidade: investigación, conservación, gestión y relación con los espacios naturales protegidos. Instituto Geológico e Minero de España, Madri, $360 \mathrm{p}$.

CENDRERO, A. 1996. El patrimonio geológico. Ideas para su protección, conservación y utilización. In: MOPTMA. El Patrimonio Geológico. Bases para su valoración, protección, conservación y utilización. Madrid, Ministério de Obras Públicas, Transportes y Médio Ambiente, 112 p.

CUMBE, A. N. F. 2007. O Patrimônio Geológico de Moçambique: Proposta de Metodologia de Inventariação, Caracterização e Avaliação. Escola de Ciências, Departamento de Ciências da Terra, Universidade do Minho, Dissertação de Mestrado em Patrimônio Geológico e Geoconservação, 240 p.

GARCIA-CORTÉS A; CARCAVILLA URQUI, L. 2009. Documento metodológico para la elaboración del inventario Español de lugares de interés geológico (IELIG). Version 11, 12-03-2009. Instituto Geológico y Minero de
España. Disponível em: http://w.igme.es/ internet/patrimonio. Acessado em 23/Mar/09.

LIMA, F. F. 2008. Proposta metodológica para a inventariação do Patrimônio Geológico Brasileiro. Escola de Ciências, Universidade do Minho, Portugal, Dissertação de Mestrado em Patrimônio Geológico e Geoconservação, 90 p.

LIMA, M. R. 1989. Fósseis do Brasil. Editora da Universidade de São Paulo, São Paulo, 334 p.

MEZZALIRA, S. 1952. Clarkecaris, novo gênero de crustáceo Syncarida do Permiano. São Paulo, Sociedade Brasileira de Geologia, p. 46-51 (Boletim, 1/1).

PEREIRA, R. G. F. A. 2010. Geoconservação e desenvolvimento sustentável na Chapada Diamantina (Bahia - Brasil). Escola de Ciências, Universidade do Minho, Braga (Portugal), Tese de Doutorado, $295 \mathrm{p}$.

PERROTTA, M.M; SALVADOR, E.D.; LOPES, R.C.; D'AGOSTINO, L.Z.; PERUFFO, N.; GOMES, S.D.; SACHS, L.L.B.; MEIRA, V.T.; GARCIA, M.G.M.; LACERDA FILHO, J.V. 2005. Mapa Geológico do Estado de São Paulo, escala 1:750.000. Programa Geologia do Brasil, PGB, CPRM, São Paulo.

SÃO PAULO. 1968. Lei $n^{\circ} 10.247 / 1968$. Resolução $n^{\circ} 76$, de 05 de novembro de 2009. Dispõe sobre a competência, organização e o funcionamento do Conselho de Defesa do Patrimônio Histórico, Arqueológico, Art íst ico e Tur íst ico do Estado, criado pelo Art igo 128 da Const ituição Estadual e dá outras providências. São Paulo, Secretaria de Estado da Cultura. Diário Oficial de 05/11/2009, Seção 1, p. 42.

SÃO PAULO. 2009. Resolução no 76, de 05 de novembro de 2009. Dispõe sobre a criação do Conselho Estadual de Monumentos Geológicos. São Paulo, Secretaria de Estado do Meio, Diário Oficial de 05/112009, Seção 1, p. 42.

SEADE - FUNDAÇÃO SISTEMA ESTADUAL DE ANÁLISE DE DADOS. 2011. Perfis Municipais. Disponível em http://www. seade.gov.br/produtos/perfil/. Acessado em dez./2011.

SHARPLES, C. 2002. Concepts and principles of geoconservation. Published electronically 
on the Tasmanian Parks \& Wildlife Service website. Disponível em http://www.dpiw. tas.gov.au/inter,nsf/Attachments/SJON57W3 YM/\$FILE/geoconservation.pdf. Acessado em 21/nov./2013.

STANLEY, M. 2000. Geodiversity. Earth Heritage, 14: $15-18$.

TOLEDO, C. E. V. 2006. Análise estatística multivariada e filogenética dos dipnoiformes brasileiros. Comparações bióticas com o Gondwana Ocidental. Instituto de Geociências e Ciências Exatas, Universidade Estadual Paulista "Júlio de Mesquita Filho", Rio Claro, Tese de Doutorado, $212 \mathrm{f}$.

UCEDA, A.C. 2000. Patrimônio geológico; diagnóstico, clasificación y valoración. In: J. P.
Suárea-Valgrande (coord.) Jornadas sobre Patrimônio Geológico y Desarrollo Sostenible, Espana, Soria, Ministério de Medio Ambiente, serie Monografias, p. 23-37.

WIMBLEDON, W. A. P.; ANDRESEN S.; CLEAL, C. J.; COWIE, J. W.; ERIKSTAD, L.; GONGGRIJP, G. P.; JOHANSSON, C. E.; KARIS, L. O.; SOUMINEN, 1999. Geological World Heritage: GEOSITES a global comparative site inventory to enable prioritsation for conservation. In: Mem. Descr. Carta Geol. D'It. LIV, p 45-60.

ZAINE, M.F., PERINOTTO, J.A.J. 1996. Patrimônio natural e história geológica da região de Rio Claro/SP. Arquivo Público e Histórico do município de Rio Claro, Rio Claro, 91p.

\section{Endereço dos autores:}

Rogério Rodrigues Ribeiro - Instituto Geológico, Secretaria de Estado do Meio Ambiente de São Paulo, Av. Miguel Stéfano, 3900, Água Funda, CEP: 04301-903, São Paulo, SP. E-mail: rrribeiro@igeologico. sp.gov.br

Sergio Ricardo Christofoletti - Instituto Florestal, Secretaria de Estado do Meio Ambiente de São Paulo, Av. Navarro de Andrade S/N, Vila Paulista , CEP: 13.500-970, Rio Claro, SP. E-mail: sergioricardoc@ gmail.com

Alessandro Batezelli - Instituto de Geociências, Universidade Estadual de Campinas, Rua João Pandiá Calógeras, 51, Cidade Universitária, CEP: 13083-870, Campinas, SP. E-mail: abatezelli@ige.unicamp.br

Fernando Cilento Fittipaldi - Instituto Geológico - Secretaria de Estado do Meio Ambiente de São Paulo. In memoriam.

Denise Zanchetta - Instituto Florestal, Secretaria de Estado do Meio Ambiente de São Paulo, Rua do Horto, 931, Horto Florestal, CEP: 02377-000, São Paulo, SP. E-mail: dzanchettazanchetta@gmail.com

Artigo submetido em 22 de agosto de 2013, aceito em 25 de novembro de 2013. 
